\title{
Dismantlement and Radioactive Waste Management of DPRK Nuclear Facilities
}

\author{
Professor WHANG Jooho \\ Kyung-Hee University \\ Seoul, Republic of Korea \\ and \\ Dr. George T. Baldwin \\ Sandia National Laboratories \\ Albuquerque, NM USA
}

Cooperative Monitoring Center Occasional Paper

\section{i. Sandia National Laboratories}

Sandia is a multiprogram laboratory operated by

Sandia Corporation, a Lockheed Martin Company,

for the United States Department of Energy's

National Nuclear Security Administration

under contract DE-AC04-94AL85000. 
The Cooperative Monitoring Center (CMC) at Sandia National Laboratories assists political and technical experts from around the world to acquire the technology-based tools they need to assess, design, analyze, and implement nonproliferation, arms control, and other cooperative security measures. As part of its mission, the CMC sponsors research on cooperative security and the role of technology. Reports of that work are provided through the Occasional Papers series. Research is conducted by Sandia staff, international technical experts, and visiting scholars. (The CMC's Visiting Scholars Program is administered by the Institute for Public Policy at the University of New Mexico.) For additional information on the CMC's programs, visit the CMC home page on the World Wide Web at <http://www.cmc.sandia.gov> or write to:

Cooperative Monitoring Center

Sandia National Laboratories

PO Box 5800

Mail Stop 1373

Albuquerque, NM 87185-1373

For specific information on this report contact:

George Baldwin at the above address.

This report was prepared by Sandia National Laboratories

Albuquerque, NM 87185 and Livermore, CA 94550 


\section{Abstract}

One critical aspect of any denuclearization of the Democratic People's Republic of Korea (DPRK) involves dismantlement of its nuclear facilities and management of their associated radioactive wastes. The decommissioning problem for its two principal operational plutonium facilities at Yongbyun, the 5MWe nuclear reactor and the Radiochemical Laboratory reprocessing facility, alone present a formidable challenge. Dismantling those facilities will create radioactive waste in addition to existing inventories of spent fuel and reprocessing wastes.

Negotiations with the DPRK, such as the Six Party Talks, need to appreciate the enormous scale of the radioactive waste management problem resulting from dismantlement. The two operating plutonium facilities, along with their legacy wastes, will result in anywhere from 50 to 100 metric tons of uranium spent fuel, as much as 500,000 liters of liquid high-level waste, as well as miscellaneous high-level waste sources from the Radiochemical Laboratory. A substantial quantity of intermediate-level waste will result from disposing 600 metric tons of graphite from the reactor, an undetermined quantity of chemical decladding liquid waste from reprocessing, and hundreds of tons of contaminated concrete and metal from facility dismantlement. Various facilities for dismantlement, decontamination, waste treatment and packaging, and storage will be needed. The shipment of spent fuel and liquid high level waste out of the DPRK is also likely to be required.

Nuclear facility dismantlement and radioactive waste management in the DPRK are all the more difficult because of nuclear nonproliferation constraints, including the call by the United States for "complete, verifiable and irreversible dismantlement," or "CVID." It is desirable to accomplish dismantlement quickly, but many aspects of the radioactive waste management cannot be achieved without careful assessment, planning and preparation, sustained commitment, and long completion times. The radioactive waste management problem in fact offers a prospect for international participation to engage the DPRK constructively. DPRK nuclear dismantlement, when accompanied with a concerted effort for effective radioactive waste management, can be a mutually beneficial goal. 
Dismantlement and Radioactive Waste Management of DPRK Nuclear Facilities

This page left intentionally blank. 


\section{Contents}

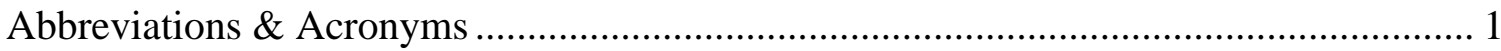

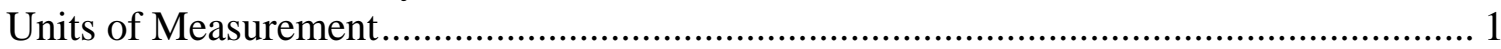

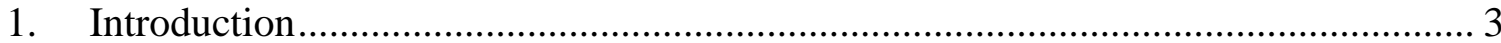

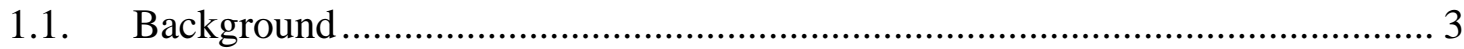

1.2. Objectives of Dismantlement................................................................... 4

1.3. Consequences of Dismantlement................................................................... 4

1.4. Need for Technical Work in Advance ................................................................ 5

1.5. Contribution of this study …………………............................................. 5

2. Plutonium-Relevant Nuclear Facilities ............................................................. 7

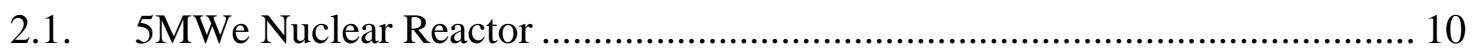

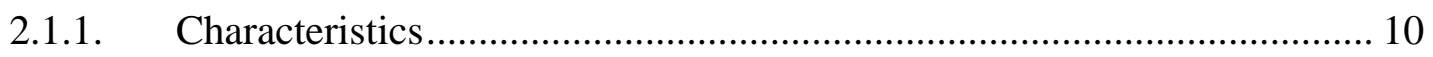

2.1.2. Operational History and Status .............................................................. 12

2.1.3. Spent Fuel Arising ……………………….......................................... 12

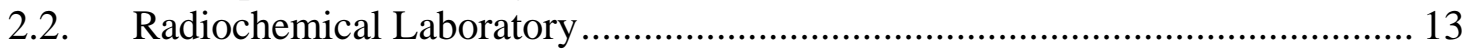

2.2.1. Characteristics............................................................................... 13

2.2.2. Operational History and Waste.................................................................. 16

3. Decommissioning the 5MWe Reactor and Related Facilities ................................... 19

3.1. Decommissioning Options............................................................................ 20

3.2. Decommissioning the 5MWe Reactor ......................................................... 20

3.2.1. Nuclear Graphite Waste ................................................................................. 21

3.2.2. International Status of Graphite Reactor Decommissioning ...................... 21

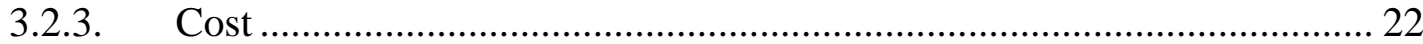

3.2.4. Decommissioning of Key Elements...................................................... 22

3.3. Decommissioning the Radiochemical Laboratory........................................... 27

3.3.1. International Precedents for Reprocessing Facility Decommissioning .... 27

3.3.2. Decommissioning of Key Elements......................................................... 28

3.4. Basic Schemes for Decommissioning.......................................................... 31

3.4.1. Spent Fuel and the 5MWe Reactor ........................................................... 31

Liquid HLW, Chemical Decladding Waste, and the Radiochemical Laboratory..... 34

3.4.2. Facilities Required for Waste Management in the DPRK .......................... 36

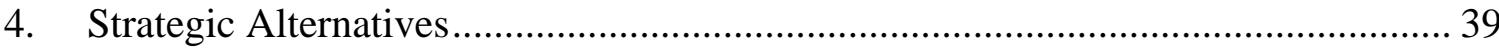

4.1. $\quad$ Fast Track Decommissioning ……………..................................................... 39

4.2. Decommissioning Supported by International Cooperation................................ 40

5. Conclusions and Recommendations ...................................................................... 41

Appendix I: Status of Graphite Reactor Decommissioning................................................ 43

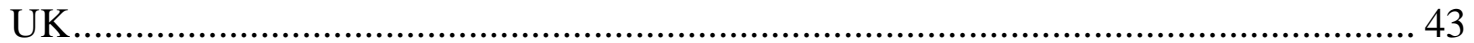

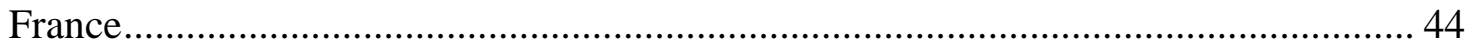

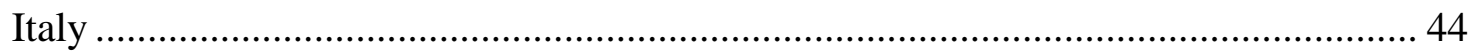

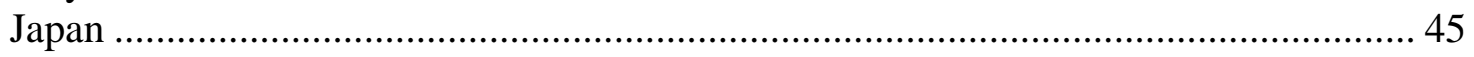

Appendix II: International Precedents for Reprocessing Facility Decommissioning....... 47

Eurochemic Facility Decommissioning.................................................................... 47

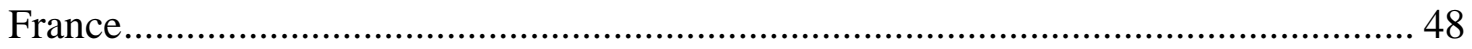




\section{Figures}

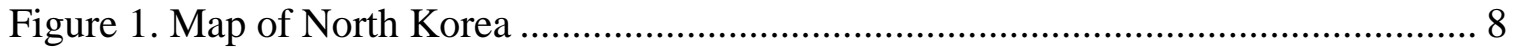

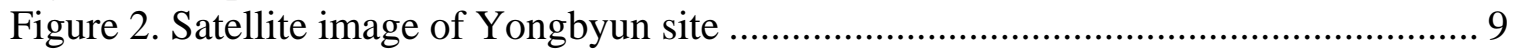

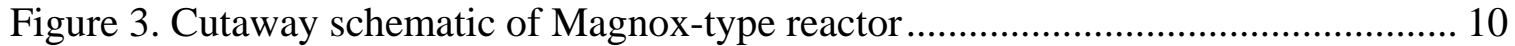

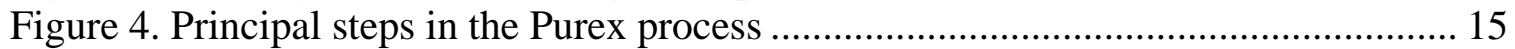

Figure 5. Schematic flow for spent fuel: from defueling the 5WMe reactor to disposal

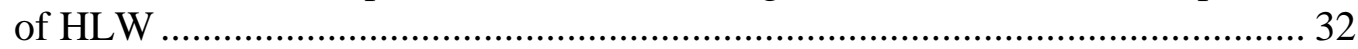

Figure 6. Schematic flow for solid wastes from dismantling the 5WMe reactor ............. 33

Figure 7. Schematic flow for liquid HLW stored at the Radiochemical Laboratory........ 34 Figure 8. Schematic flow for Chemical Decladding Waste stored at the Radiochemical

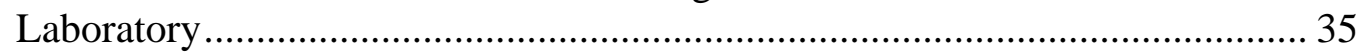

Figure 9. Schematic flow for solid wastes from the Radiochemical Laboratory.............. 36

\section{Tables}

Table 1. Status of Nuclear Facilities in the DPRK …..................................................... 7

Table 2. Characteristics of the 5MWe reactor (estimated) ............................................ 11

Table 3. Estimate of the waste generated from the Radiochemical Laboratory ................ 17

Table 4. Decommissioning Cost for Selected Reactor Types.......................................... 22

Table 5. Spent Fuel Cost based on LWR Fuel Cycle Unit Prices.................................... 25

Table 6. Facilities needed to manage the wastes from decommissioning the 5WMe reactor and the Radiochemical Laboratory ..................................................... 37 


\section{Abbreviations \& Acronyms}

$\begin{array}{ll}\text { BWR } & \text { Boiling Water Reactor } \\ \text { CANDU } & \text { Canadian Deuterium Uranium (reactor type) } \\ \text { CVID } & \text { Complete, Verifiable \& Irreversible Dismantlement } \\ \text { DPRK } & \text { Democratic People’s Republic of Korea (North Korea) } \\ \text { GCR } & \text { Gas Cooled Reactor (In all cases discussed in this report, these are } \\ & \quad \text { equivalently “graphite-moderated” reactors.) } \\ \text { HLW } & \text { High Level (Radioactive) Waste } \\ \text { IAEA } & \text { International Atomic Energy Agency } \\ \text { ILW } & \text { Intermediate Level (Radioactive) Waste } \\ \text { LLW } & \text { Low Level (Radioactive) Waste } \\ \text { LWR } & \text { Light Water Reactor } \\ \text { NEA } & \text { Nuclear Energy Agency (unit of OECD) } \\ \text { NGO } & \text { Non-Governmental Organization } \\ \text { NRC } & \text { Nuclear Regulatory Commission (US) } \\ \text { OECD } & \text { Organization for Economic Co-operation and Development (Europe) } \\ \text { PWR } & \text { Pressurized Water Reactor } \\ \text { RDD } & \text { Radioactive Dispersal Device } \\ \text { ROK } & \text { Republic of Korea (South Korea) } \\ \text { UK } & \text { United Kingdom } \\ \text { US } & \text { United States } \\ \text { WAGR } & \text { Windscale Advanced Gas Cooled Reactor }\end{array}$

\section{Units of Measurement}

$\begin{array}{ll}\text { BF } & \text { Belgian Franc } \\ \mathrm{Ci} & \text { Curie (measure of radioactivity) } \\ \mathrm{DM} & \text { Deutsch Mark } \\ \mathrm{g} & \text { Gram } \\ \mathrm{g} / \mathrm{cm}^{3} & \text { Gram per cubic centimeter (measure of density) } \\ \mathrm{kgU} & \text { kilogram-Uranium } \\ \mathrm{kWe} & \text { kilowatt-electric } \\ \mathrm{m} & \text { Meter } \\ \mathrm{MW} & \text { Megawatt } \\ \mathrm{MWD} / \mathrm{tU} & \text { Megawatt-days per tonne Uranium (measure of reactor fuel burnup) } \\ \mathrm{MWe} & \text { Megawatt-electric } \\ \mathrm{MWth} & \text { Megawatt-thermal } \\ \mathrm{SWU} & \text { Separative Work Unit (measure of enrichment) } \\ \mathrm{t} & \text { metric ton } \\ \mathrm{tU} & \text { metric tons uranium } \\ \mathrm{USD} & \text { US Dollar (\$) }\end{array}$


Dismantlement and Radioactive Waste Management of DPRK Nuclear Facilities

This page left intentionally blank. 


\section{Introduction}

\subsection{Background}

The North Korean nuclear weapons program has drawn serious international attention since the early 1990s. In 1994, North Korea (DPRK) agreed to freeze its nuclear weapons program in exchange for energy and economic aid by the United States (US) and South Korea (ROK), including the provision of two Light Water Reactor (LWR) units and arrangement for interim energy alternatives. According to the so-called "Agreed Framework" between the US and DPRK, the DPRK agreed eventually to dismantle its graphite-moderated reactors and related facilities. The US and DPRK were supposed to cooperate in finding a method to store the spent nuclear fuel, and to dispose of it in a safe manner that does not involve reprocessing in the DPRK. The dismantlement was supposed to be accomplished within ten years from the conclusion of the agreement. However, the technical and economical aspects of dismantlement had not been treated in detail.

The main facilities of concern include the 5 MWe graphite moderated reactor that had been operated since 1986 for the primary purpose of producing plutonium for nuclear weapons. Larger units, rated at $50 \mathrm{MWe}$ and $200 \mathrm{MWe}$, were constructed but never operated. A large reprocessing facility (the "Radiochemical Laboratory") has been operated to recover plutonium from the reactor spent fuel. All of these facilities are located within several kilometers of each other, near Yongbyun, DPRK.

Unfortunately, the DPRK ignored international norms and eventually broke the Agreed Framework, which has increased tensions. Monitoring by the International Atomic Energy Agency (IAEA) was suspended when inspectors were expelled in 2002, and the DPRK is suspected to have resumed its push to develop nuclear weapons.

In 2002, negotiations resumed at the "Six Party Talks," which involve the DPRK, South Korea, the US, China, Russia, and Japan. The Six Party Talks went through a third round in June 2004. North Korea declined to participate in the fourth round of talks that had been scheduled for September 2004. Although continuation of the talks remains in limbo as of this writing, it is nevertheless very possible that the talks could resume at any time.

Denuclearization of the DPRK, especially disposition of nuclear materials and spent nuclear fuel, is a critical component of improving regional stability. Many papers have dealt strategically ${ }^{1,2,3}$ with how the North Korean nuclear weapon program would be frozen and eliminated in a complete, irreversible, and verifiable manner, if an agreement

\footnotetext{
${ }^{1}$ Leon V. Sigal, Disarming Strangers: Nuclear Diplomacy with North Korea, Princeton University Press (1999).

2 Duk-ho Moon, North Korea's Nuclear Weapons Program: Verification Priorities and New Challenges, Cooperative Monitering Center Occasional Paper, SAND 2003-4558, Sandia National Laboratories (2003).

${ }^{3}$ David Albright and Corey Hinderstein, "Verifiable, Irreversible, Cooperative Dismantlement of the DPRK's Nuclear Weapons Program,” Proceedings of the Institute of Nuclear Materials Management, $45^{\text {th }}$ Annual Meeting (2004).
} 
can be reached. Technical papers ${ }^{4,5}$ have mostly been concerned with how to verify and reveal the status and history of its nuclear weapons program.

\subsection{Objectives of Dismantlement}

Denuclearization could involve several related issues or objectives. One objective is to discontinue current production of nuclear weapon usable material, particularly plutonium. Another objective would be to prevent future production of the material. An additional objective would be to enable forensic analysis to determine the past production of material. Further objectives include finding and accounting for all existing material, and then removing or otherwise disposing of that material.

A serious concern related to denuclearization is preventing the use of radioactive waste as source material for a radioactive dispersal device (RDD, or “dirty bomb”). Cleaning up the environmental mess associated with the nuclear program is still another important issue, and would be of particular concern to reunification advocates.

A political agreement would decide which of these objectives are encompassed. Whatever the eventual settlement is, it is certain that radioactive waste management will be a critical issue.

\subsection{Consequences of Dismantlement}

Key steps in denuclearization include disposing nuclear materials and dismantling the facilities. Each step consists of many procedural components for which technologies to be applied should be sought in economically viable and proliferation-resistant ways. Many issues associated with denuclearization need to be dealt with in advance. These include preparing and conditioning nuclear materials and the spent nuclear fuel for interim storage and shipping, reprocessing the spent fuel, solidifying high-level waste (HLW) stored in tanks, and storing and disposing of solid waste from dismantlement.

Dismantling the nuclear facilities will generate a large volume of radioactive waste containing various levels of radioactivity to be treated and disposed of safely.

Considering that it may have inherited the poor radioactive waste management practices of the former Soviet Union, the DPRK may not be operating nuclear facilities in compliance with international safety standards.

We do not foresee North Korea, unlike South Africa, including the radioactive waste problem as part of the denuclearization process. South Africa dismantled its weapons program and managed the resultant radioactive waste without foreign assistance. Verification of South Africa's dismantlement by the IAEA was complicated by lack of knowledge of the nuclear weapons program infrastructure, and took approximately two years.

\footnotetext{
${ }^{4}$ Jared S. Dreicer, “How Much Plutonium Could Have been Produced in the DPRK IRT Reactor?” Science and Global Security, vol 8, pp 273-286 (2000).

${ }^{5}$ David Albright, “North Korea's Current and Future Plutonium and Nuclear Weapon Stocks,” ISIS Issue Brief, Institute for Science and International Security, January 15, 2003.
} 


\subsection{Need for Technical Work in Advance}

Dismantling nuclear facilities and safely disposing of spent nuclear fuel are two main topics in the nuclear field, since they take the most time to accomplish and require large resources of money, manpower, technology, and regulatory work. Dismantling the infrastructure of a nuclear weapons program involves a long listing of contents that are so complicated, technically as well as economically, that allocation of responsibilities among the interested parties may take too long to be finalized in an expected time frame. After reaching a strategic dismantlement agreement, substantial issues regarding roles and responsibilities would remain and would require extensive discussion to resolve.

Allocating these responsibilities to the participants will be decided at the working level of the Six Party Talks, so estimating in advance the resources needed to dismantle the facilities and to treat the radioactive waste from the nuclear facilities will help prepare for the talks. As a spin-off benefit, creating a good scheme for cooperation would be a starting point for, or component of, multilateral management of the nuclear fuel cycle in East Asia. This will consequently enhance the nonproliferation regime.

\subsection{Contribution of this study}

The scope of this work is limited to the plutonium-relevant nuclear facilities in the DPRK, specifically the 5MWe graphite reactor and the associated Radiochemical Laboratory. These key plutonium-producing DPRK facilities are relatively well-known, which makes estimation possible. Less is known about the suspected uranium enrichment program, which makes estimating the associated radioactive waste management from dismantlement difficult. It can be safely assumed, however, that such consequences only add to the consequences we deal with in this study, namely those from the plutonium program. From a technical point of view, the plutonium program dismantlement would probably be the most problematic.

The objectives of this study are to address key issues and critical paths for dismantling the two plutonium generating facilities in the DPRK from the radioactive waste management perspective. We will examine the substantive issues that estimate the amount of waste resulting from dismantling the DPRK nuclear facilities, and, based upon international experiences, estimate the time it would take to dismantle, which would help generate strategies for the future. We will develop various scenarios or alternatives for comparison, including final disposition of nuclear materials and spent nuclear fuel, emphasizing technical aspects.

This study should help anticipate the barriers that the participants at the Six Party Talks may encounter while proceeding to reach an agreement. We expect to provide technical information that can be useful in evaluating policy options with respect to the stated goal of "complete, verifiable and irreversible dismantlement" (CVID).

Government entities from all of the six-party countries need to consider the technical implications of any forthcoming political agreement and should be interested in the result of this study. In the US, both the Departments of State and Energy are directly involved. In South Korea, the list includes the Ministry of Foreign Affairs and Trade, Ministry of Unification, and Ministry of Science and Technology. In addition, government-affiliated research institutes, non-governmental organizations dealing with security policy, strategy 
studies, or Korean unification, as well as professional technical societies, are an extended audience for this work. 


\section{Plutonium-Relevant Nuclear Facilities}

The known nuclear facilities in the DPRK are listed in Table 1. Only the two research reactors and the 5MWe power reactor have been operational. Construction of the other reactors has not been completed. These reactors would be new threats if their construction resumed and operations began, but otherwise their decommissioning would not be a major issue.

Table 1. Status of Nuclear Facilities in the DPRK

\begin{tabular}{|l|l|l|}
\hline Type & Location (number) & Remarks \\
\hline Nuclear Power Reactor & $\begin{array}{l}\text { Yongbyun(2) } \\
\text { Taechon(1) } \\
\text { Shinpo(2) }\end{array}$ & $\begin{array}{l}5 \text { MWe, 50 MWe } \\
\text { 200 MWe } \\
1000 \text { MWe }\end{array}$ \\
\hline Research Reactor & Pyungyang(1) & for education \\
Fongbyun(1) & IRT-2000, radioisotope production \\
\hline $\begin{array}{l}\text { Fuel Fabrication Facility } \\
\text { (reprocessing plant) }\end{array}$ & Yongbyun(1) & two processing lines \\
\hline Uranium Mine & Yongbyun(1) & \\
\hline Uranium Milling & Pyungsan(1), Sunchun(1) & \\
\hline Isotope Processing Facility & Yongbyun(1) & 290 tU/year, 210 tU/year \\
\hline
\end{tabular}

The nuclear facility locations can be found on the map in Figure 1. A commercial satellite image of the Yongbyun facilities is in Figure 2. 
Figure 1. Map of North Korea

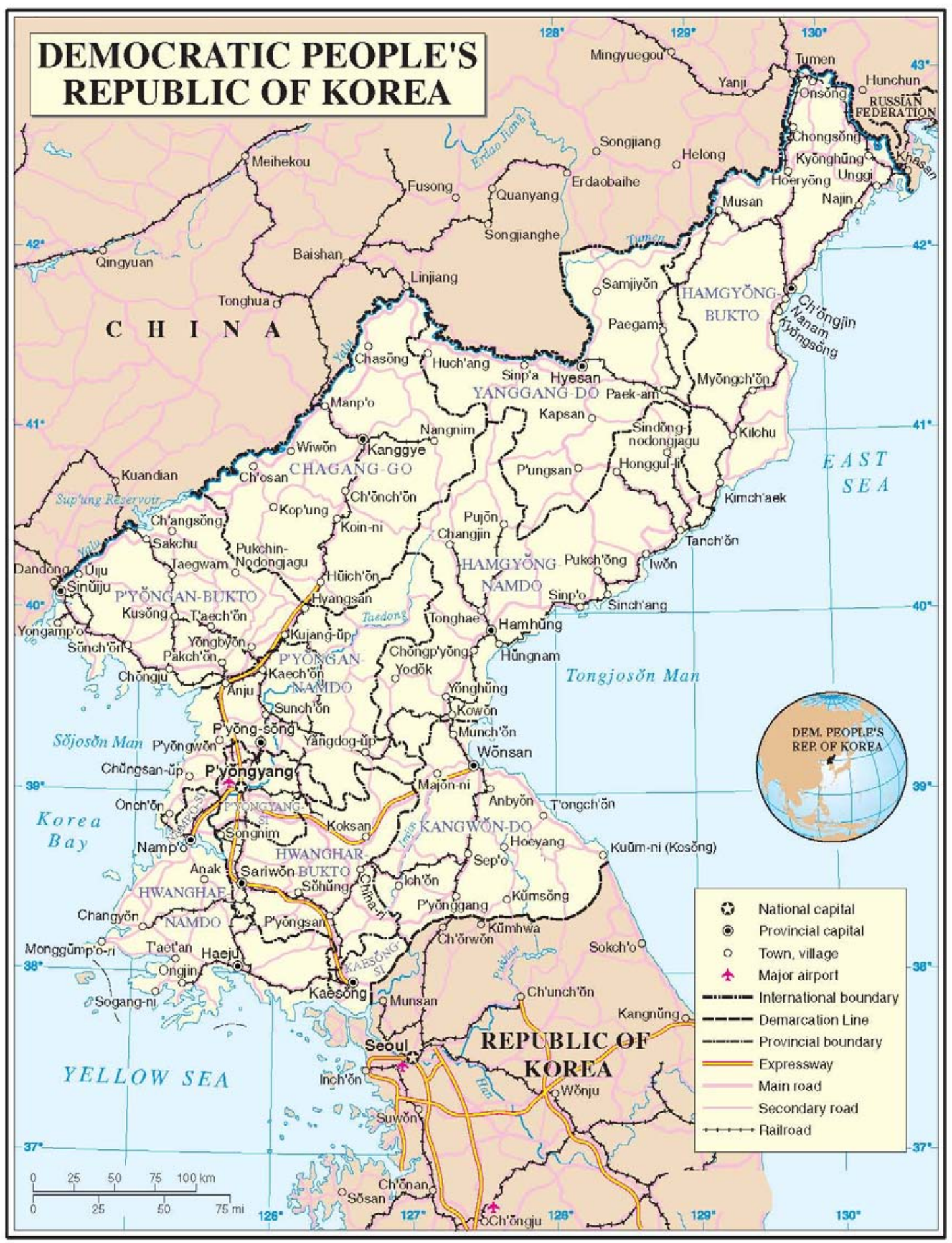


Figure 2. Satellite image of Yongbyun site ${ }^{6}$

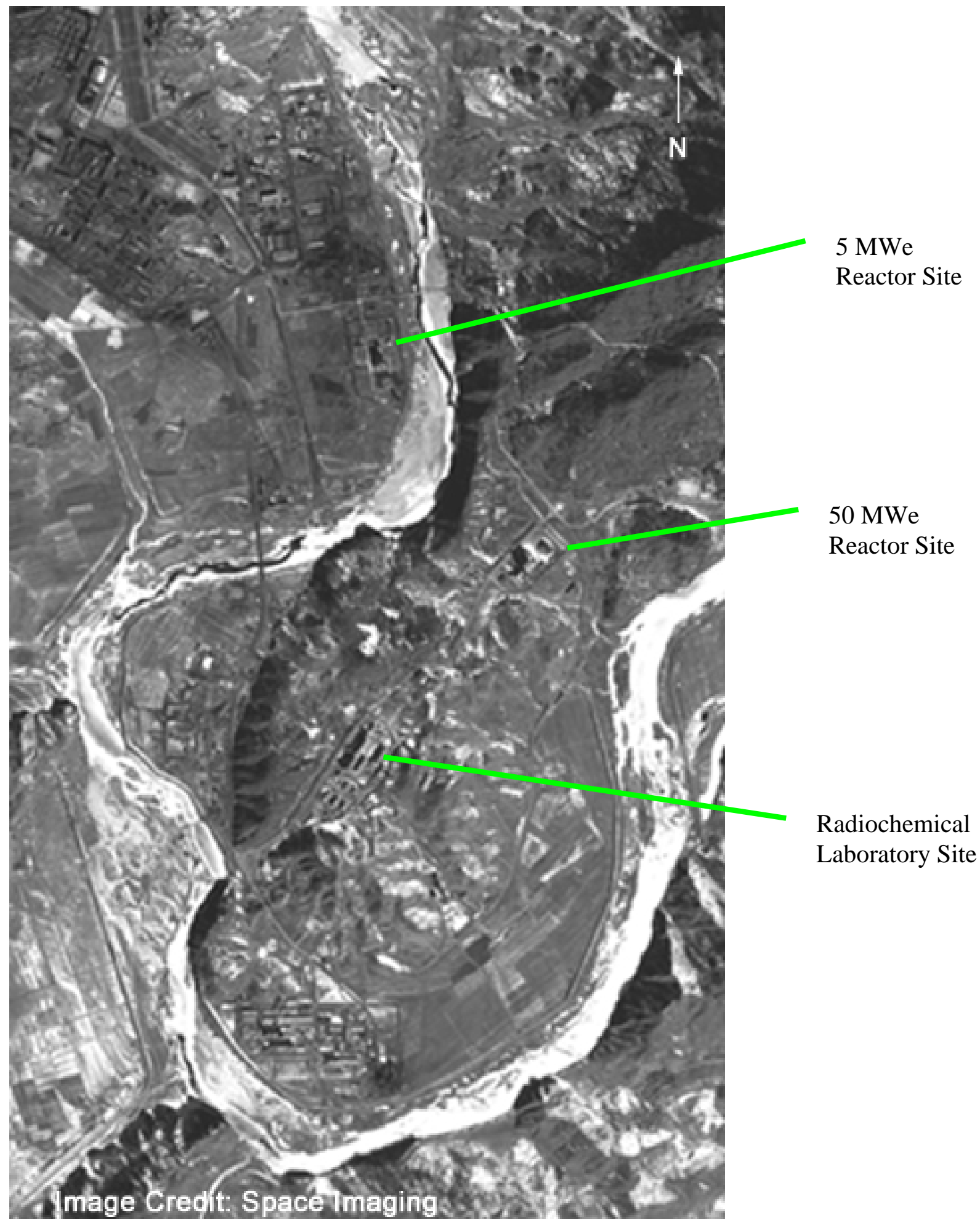

${ }^{6}$ IKONOS 1-m commercial satellite image of Yongbyun nuclear site, DPRK, in early 2000, as cited by David Albright and Corey Hinderstein in Solving the North Korean Nuclear Puzzle, Chapter 3, Institute for Science and International Security [ref: http://www.isis-online.org/publications/dprk/book/figures2_3.html]. 


\section{1. $\quad 5 M W e$ Nuclear Reactor}

\subsubsection{Characteristics}

The 5MWe graphite reactor at Yongbyun is a Magnox-type reactor. Magnox reactors (see Figure 3) have a graphite-moderated reactor core that is cooled by carbon dioxide gas. The uranium fuel can be loaded and unloaded from the top of the reactor while the reactor is in operation. Fresh fuel is supplied from a fuel fabrication plant located at the same site. Spent fuel withdrawn from the reactor is transferred to a storage pool.

Figure 3. Cutaway schematic of Magnox-type reactor

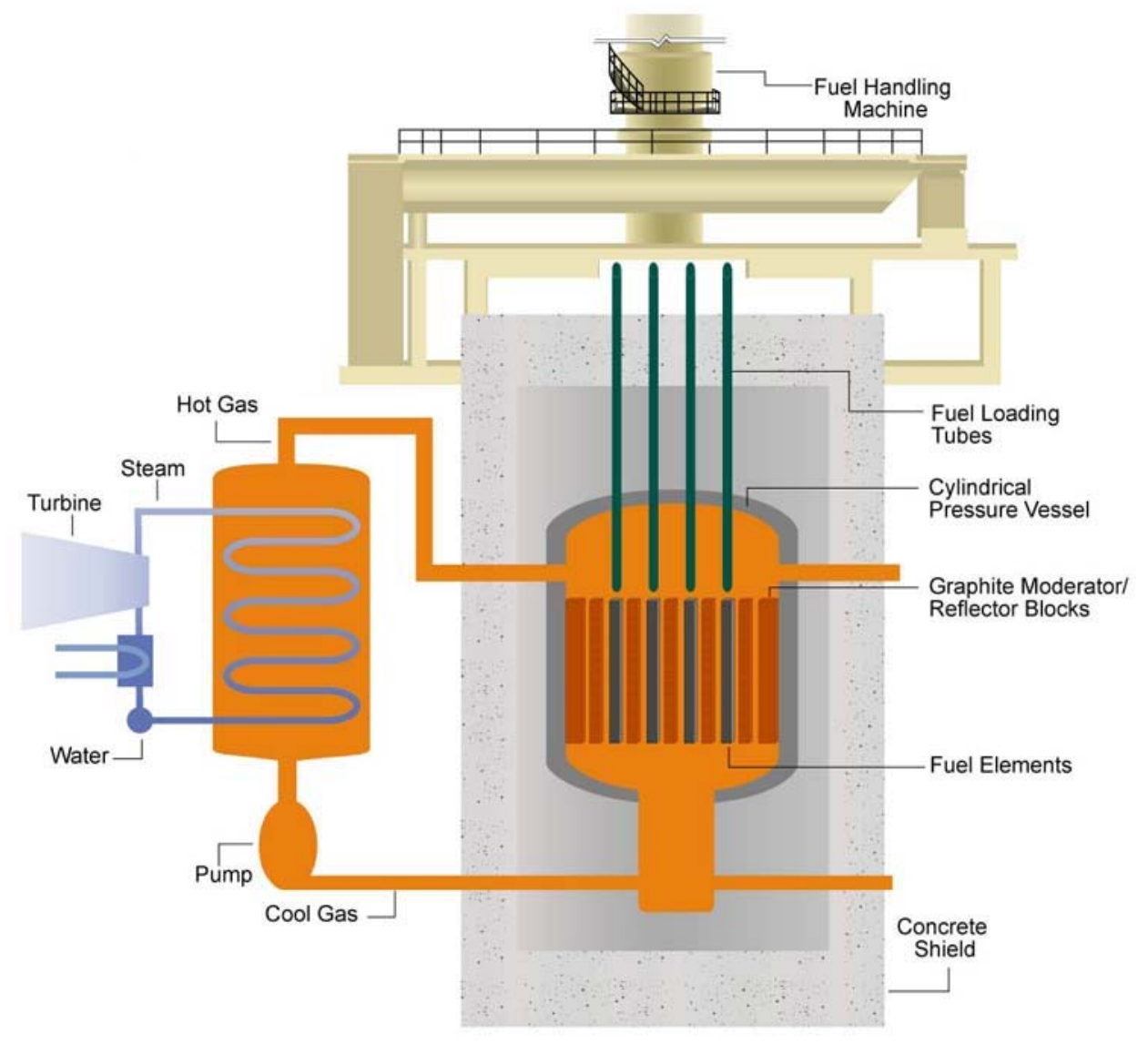

The name "Magnox" comes from the cladding of the uranium fuel, which is an alloy of magnesium. The fuel itself is uranium metal, which corrodes much more easily than uranium oxide fuel found in light water reactors. When in contact with water, metallic uranium converts to uranium oxide and uranium hydride. Both uranium metal and uranium hydride are pyrophoric, which presents a fire hazard.

Exact design features of the 5MWe reactor have not been released by the DPRK, but it is reported to have adopted the design of the UK “Calder Hall” reactors. The Calder Hall reactors began operation in 1956, producing weapons-grade plutonium and electricity on 
a small scale. Researchers estimate the design characteristics of the 5MWe reactor as in Table $2 .^{7}$

Table 2. Characteristics of the 5MWe reactor (estimated)

\begin{tabular}{|c|c|}
\hline $\begin{array}{l}\text { Power, thermal } \\
\text { Power, electric }\end{array}$ & $\begin{array}{l}20 \text { MWth } \\
5 \text { MWe }\end{array}$ \\
\hline $\begin{array}{l}\text { Burnup }^{8} \text {, maximum } \\
\text { Burnup, average }\end{array}$ & $\begin{array}{l}\text { 1,370 MWD/tU } \\
635 \mathrm{MWD} / \mathrm{tU}\end{array}$ \\
\hline $\begin{array}{l}\text { Initial Fuel Loading } \\
\text { Graphite Moderator } \\
\text { Graphite Reflector }\end{array}$ & $\begin{array}{l}50 \mathrm{tU} \\
300 \mathrm{t} \\
300 \mathrm{t}\end{array}$ \\
\hline $\begin{array}{l}\text { Reactor Core } \\
\text { Effective Height } \\
\text { Effective Diameter } \\
\text { Number of Fuel Channels } \\
\text { Fuel Elements/Channel }\end{array}$ & $\begin{array}{l}590 \mathrm{~cm} \\
643 \mathrm{~cm} \\
812 \\
10\end{array}$ \\
\hline $\begin{array}{l}\text { Fuel Elements } \\
\text { Core } \\
\text { Cladding } \\
\text { Diameter } \\
\text { Length } \\
\text { Uranium Mass }\end{array}$ & $\begin{array}{l}\text { natural uranium-0.5\% aluminum } \\
\text { magnesium-0.5\% zirconium } \\
3.0 \mathrm{~cm} \\
60 \mathrm{~cm} \\
6.24 \mathrm{~kg}\end{array}$ \\
\hline $\begin{array}{l}\text { Reactor Vessel (steel) } \\
\text { Inner Diameter } \\
\text { Height } \\
\text { Thickness }\end{array}$ & $\begin{array}{l}880 \mathrm{~cm} \\
1,680 \mathrm{~cm} \\
4.0 \mathrm{~cm}\end{array}$ \\
\hline $\begin{array}{l}\text { Shield } \\
\text { Thermal Shield (steel) Thickness } \\
\text { Upper Concrete Thickness } \\
\text { Radial Concrete Thickness }\end{array}$ & $\begin{array}{l}7.0 \mathrm{~cm} \\
450 \mathrm{~cm} \\
300 \mathrm{~cm}\end{array}$ \\
\hline
\end{tabular}

${ }^{7}$ David Albright and Kevin O’Neill, ed., Solving the North Korean Nuclear Puzzle, The Institute for Science and International Security, Washington D.C., 2000, 161-2.

${ }^{8}$ Specific burnup of the fuel is termed as the fission energy released per unit mass of the fuel, usually expressed in megawatt days per metric ton or per kg, i.e., MWD/tU or MWD/kgU. 


\subsubsection{Operational History and Status}

The operational history is a key factor with regard to nonproliferation purposes to determine the amount of spent fuel discharged and, consequently, the amount of plutonium contained in the spent fuel.

The DPRK began construction of the 5MWe reactor in 1980. It started operation in 1986, and had been in operation for eight years when the freeze began in 1994. The operation history of these eight years is not known, except that it had experienced some abnormalities. Verifying the operational history of the 5MWe reactor from 1986 to 1994 has been a concern to many investigators. Inconsistency between the DPRK's report to the IAEA and the independent findings of the IAEA made investigators speculate various operation options the DPRK might have taken.

In normal operation, the 5MWe reactor is expected to discharge one-fifth of the fuel in the core per year. This portion of the core contains about $6 \mathrm{~kg}$ of plutonium. Based upon all available information, and with many assumptions made to figure out the amount of spent fuel withdrawn and reprocessed, experts generally conclude that the DPRK has not drawn out more than two full cores (16,000 fuel elements).

The DPRK restarted the 5MWe reactor in February 2003. It is now claimed to operate at full power.

\subsubsection{Spent Fuel Arising}

Following the 1994 Agreed Framework, the 5MWe reactor was stopped and its full core of about 8,000 fuel elements was withdrawn. The 8,000 spent fuel elements were packaged into 400 stainless steel cans with inert gas and stored under water. IAEA inspectors sealed the cans to detect possible tampering. The spent fuel canning operation began in April 1996 and finished in mid-1999. Canning took longer than expected due to acquisition of required tools, purification of pool water, and removal of sludge from the pool bottom. Since December 2002, when the IAEA inspectors were dismissed by DPRK, nothing has been learned about what happened to the spent fuel storage cans or their contents.

Recent US visitors to the Yongbyun site confirmed that there are no longer any cans in the pool. ${ }^{9}$ The DPRK claims that they removed all 8,000 spent fuel elements from the storage pool and reprocessed them, starting in mid-January 2003 and finishing by the end of June 2003. The visitors were not able to determine that the Radiochemical Laboratory had been operated during the first half of 2003. Two possibilities are that all 8,000 spent fuel elements were reprocessed as they claimed, or that they simply moved the spent fuel elements to another storage area. A third possibility is that the DPRK reprocessed only some of the spent fuel elements, while storing the remainder elsewhere.

The number of spent fuel elements discharged from the 5MWe reactor is a serious question from the viewpoints of both nuclear material non-proliferation and radioactive waste management. If the DPRK did not reprocess the spent fuel removed from the storage pool, and just stored it without special care in a dry pit or another water pool, the

\footnotetext{
${ }^{9}$ Sigfried Hecker, testimony before the US Senate Committee on Foreign Relations, 21 Jan 2004.

[http://foreign.senate.gov/testimony/2004/HeckerTestimony040121.pdf]
} 
spent fuel may have undergone severe corrosion. Magnox spent fuel presents a spontaneous fire hazard due to uranium hydride, and may leak fission products through corroded cladding, eventually contaminating the surroundings.

The spent fuel from the 5MWe reactor has a relatively low average burnup (635 MWD/tU), which is about one-tenth that typical of CANDU reactors. Although the fuel should be less radioactive than CANDU spent fuel, it still needs a thick layer of water or concrete for radiation shielding.

\subsection{Radiochemical Laboratory}

\subsubsection{Characteristics}

The Radiochemical Laboratory is the main reprocessing facility at Yongbyun. The building is $192 \mathrm{~m}$ long, $27 \mathrm{~m}$ wide and 6 stories high. In the reprocessing building, six process cells are located on the first floor and three sampling cells are on the second floor. Spent fuel is processed in batch mode in two process lines, each with the following major components: ${ }^{10}$

- cladding dissolver

- fuel dissolver

- 30 mixer-settlers

- 5 glove boxes
20 spent fuel elements per batch

5 spent fuel elements per batch

each 80 liter capacity

for further processing of plutonium

Construction began in 1984. In 1992, the IAEA experts saw that one process line was almost completed, lacking only the final step to reduce the volume of waste. In 1994, the construction of the second process line was observed to be complete. Since then it has not been known whether the DPRK added the final step for waste volume reduction. If the HLW passes through the volume reduction step, most of the aqueous part of the waste is removed, but the radioactivity carried by the solids remains the same. Thus, the HLW becomes more concentrated in radioactivity.

Different opinions exist regarding the Radiochemical Laboratory’s capacity. One is that the facility is capable of reprocessing 220 to 250 metric tons of uranium, i.e. Magnox fuel, per year using two process lines; ${ }^{11}$ the other is based on a statement the DPRK made to a visitor that the capacity of the Radiochemical Laboratory is 110 metric tons of uranium per line per year. $^{12}$

An analysis laboratory is located to the north of the reprocessing building, and several waste-related tanks and buildings are within the facility boundary. A suspicious building was found by satellite images to connect to the reprocessing building. Its large containment structure, $67 \mathrm{~m}$ by $24 \mathrm{~m}$ by $9 \mathrm{~m}$, is probably used for storing waste from the reprocessing building. Half of the volume may be for liquid waste storage and the other half for solid waste.

\footnotetext{
${ }^{10}$ Albright and O’Neill, 154-6.

${ }^{11}$ Albright and O’Neill, 149.

${ }^{12}$ Hecker.
} 
The Purex method, a solvent extraction process, was adopted for separating plutonium. In a solvent extraction process, specific solutes dissolved in aqueous phase move to an organic solvent, due to their higher dissolution coefficients. The Purex method is commonly adopted by commercial reprocessing facilities for slightly enriched uranium fuel from power reactors.

Figure 4 shows the principal steps of the Purex process. The basic method is as applied to fuel clad with stainless steel or zircaloy, but the figure shows a possible modification for Magnox fuel that may be used by the DPRK Radiochemical Laboratory. Based on discussions so far, the DPRK-modified Purex process may include the following differences:

- In the basic Purex process, fuel with cladding is put into the fuel dissolver, shown in Figure 4 as the direct path between Step 1 and Step 2. Only the fuel material is dissolved and the cladding hull is left out. But in the DPRK case, fuel with cladding is put into a dissolver where only the cladding dissolves (Step 1.5). The solid fuel material moves to Step 2 for dissolution.

- The HLW from Step 4 is a large volume of nitric acid containing dissolved radioactive materials. In commercial reprocessing plants, nitric acid recovery systems are added to reduce the volume of the HLW, as is depicted in Step 11.

- For light water reactors with enriched uranium fuel, impure uranyl nitrate partitioned at step 5b in Figure 4 undergoes purification and conversion to recover enriched uranium. In the DPRK case, the uranium in the uranyl nitrate has no enrichment value, so Steps 8, 9, and 10 may be omitted.

This simplified process may include only the steps needed to produce plutonium, excluding auxiliary steps for waste volume reduction (Steps 8-12), which the DPRK might not have added to the process lines of the Radiochemical Laboratory. 
Figure 4. Principal steps in the Purex process ${ }^{13}$

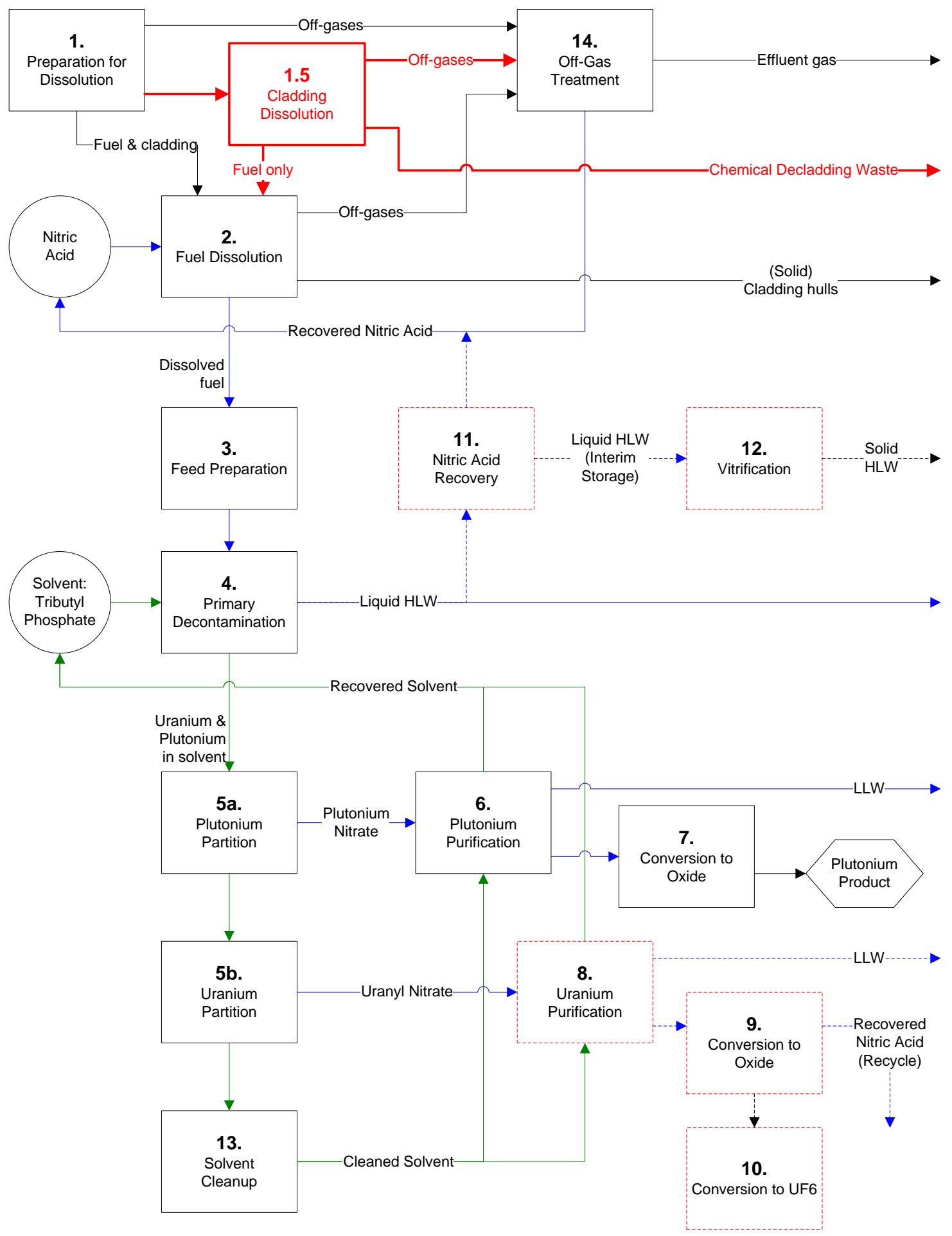

\footnotetext{
${ }^{13}$ Adapted from: Manson Benedict, Thomas Pigford, and Hans Wolfgang Levi, Nuclear Chemical Engineering, 2d ed., New York: McGraw-Hill Book Company, 1981.
} 


\subsubsection{Operational History and Waste}

The DPRK reported to IAEA in early 1989 that fresh fuel was used for a "cold test” of the reprocessing facility, followed by a hot test with 86 irradiated fuel elements. IAEA investigation found a discrepancy between the DPRK's report and sample analysis. Experts suspect, based on the results of sampling and analysis, that DPRK might have reprocessed 25 to 50 metric tons of spent fuel, corresponding to 4,000 to 8,000 spent fuel elements, during 1989 to 1991.

During Dr. Hecker's visit to the nuclear facilities of North Korea, the DPRK insisted that they had removed 8,000 canned spent fuel elements from the storage pool and reprocessed all of them.

Reprocessing generates wastes of all kinds_-gaseous, solid and liquid_-and of varying degrees of radioactivity. Wastes can be categorized in many ways. The criteria may be the level of radioactivity, concentration in the waste, the nature of the radionuclides present in the waste, and the properties of the material that carries the radioactivity. Three classifications, high-, intermediate-, and low-level waste (HLW, ILW, and LLW, respectively), are adopted in this report.

Figure 4 shows various waste streams involved in the Purex process:

- The aqueous waste stream from the primary decontamination step, Step 4 in Figure 4, is characterized as HLW. The first step in the solvent extraction separates $99-99.9 \%$ of fission products from the uranium and plutonium.

- The ILW consists of the LLW concentrate, contaminated aqueous solutions from solvent washing, and many other streams with appreciable solid content. Solutions from the cladding dissolver (hereafter termed chemical decladding waste) can be characterized as ILW. ${ }^{14}$

- The low-level liquid waste arises from the plutonium purification step and other decontamination steps. In this report, the LLW streams are ignored to highlight the two important types of waste, HLW and chemical decladding waste.

The DPRK is assumed to have operated the Radiochemical Laboratory for two main series of campaigns - the first from 1989 to 1991 as experts suspect, and the second during the first six months of 2003 as the DPRK insists. Further, it is assumed that each series reprocessed 50 metric tons of spent fuel, and that there is no facility or process line to reduce waste volume (denitration of HLW, acid recovery, etc.). A rough estimate of the maximum volumes of waste, characterized as above, is shown in Table 3.

\footnotetext{
${ }^{14}$ Jean-Marc Wolff, Eurochemic 1956-1990: Thirty-five years of international co-operation in the field of nuclear engineering: The chemical processing of irradiated fuels and the management of radioactive wastes, NEA/OECD, Paris, 1996.
} 
Table 3. Estimate of the waste* generated from the Radiochemical Laboratory

\begin{tabular}{|l|l|l|}
\hline HLW & 500,000 liters & See Note 1 \\
\hline ILW & 300,000 liters & See Note 2 \\
\hline Uranyl nitrate & about $100 \mathrm{tU}$ & See Note 3 \\
\hline
\end{tabular}

1. 5,000 liter/tU $\times 50$ tU/campaign $\times 2$ campaigns

In a typical Purex process with pulse columns (cf. the DPRK uses mixer settlers), per 1 ton uranium basis, Step 4 in Figure 4 is given 2,830 liters as feed, 17,000 liters of solvent. 4,220 liters of HLW will be sent to Step $11 .{ }^{15}$ Roughly, 5,000 liters of HLW is estimated to be generated.

2. 3,000 liter/tU $\times 50 \mathrm{tU} /$ campaign $\times 2$ campaigns

The source is mainly from chemical decladding. Chemical decladding of Mg-clad fuel at the Eurochemic plant generated $3 \mathrm{~m}^{3} / \mathrm{tU} .^{16}$

3. Impure uranyl nitrate from step $5 b$ in Figure 4.

*These are minimum estimates

${ }^{15}$ O.J. Wick et at., Plutonium Handbook: A Guide to Technology, American Nuclear Society, Illinois, 1980. ${ }^{16}$ Wolff. 
Dismantlement and Radioactive Waste Management of DPRK Nuclear Facilities

This page left intentionally blank. 


\section{Decommissioning the 5MWe Reactor and Related Facilities}

The US and the DPRK agreed in 1994 to complete dismantling the 5MWe reactor and related facilities in ten years, when a project to supply two LWRs would have been completed. The word "complete" was used in the agreement, but it was not precisely defined. It is not clear whether the word "complete" can be a qualitative goal for dismantling the 5MWe reactor and its related facilities and whether the time period of ten years is enough. International practices are referenced in this report for helpful hints and to provide a technical basis for the Six Party Talks.

To date, 90 commercial power reactors, more than 250 research reactors, and many other nuclear fuel cycle facilities worldwide have been shut down. Some of them have been fully dismantled. Most of the Magnox-type reactors in UK, France, Italy, and Japan have also been shut down, some as far back as the 1980s. Shutting down Magnox reactors has sometimes been delayed in order to determine decommissioning strategies.

The IAEA, OECD/NEA, and the World Nuclear Association have compiled the amount of experience countries with advanced nuclear fuel cycles have with decommissioning reprocessing plants. Generally, proven techniques and equipment are available for decommissioning such nuclear facilities. More effort is required to compare cost data from many countries in a standard format.

Factors to be taken into account when developing a strategy from available options for decommissioning include:

- Safety and environmental issues,

- Requirements for possible reuse of the plant and/or site,

- Quantity and types of waste produced,

- Availability of waste disposal sites,

- Worker dose,

- Cost and availability of funding,

- Consideration of sustainability and intergenerational equity arguments and stakeholder views.

In the DPRK case, special consideration has to be given for the decommissioning strategy to support nuclear nonproliferation and security issues.

In this section, we review technical options for decommissioning the key elements of the 5MWe reactor and the Radiochemical Laboratory. Considering both technical feasibility and international experiences, strategic alternatives will be sought in a later section. 


\subsection{Decommissioning Options}

Three options for decommissioning have been defined by the International Atomic Energy Agency: DECON, SAFSTOR, and ENTOMB. ${ }^{17}$

\section{DECON}

DECON involves “immediate” dismantlement. Soon after the nuclear facility closes, equipment, structures, and portions of the facility containing radioactive contaminants are removed and decontaminated to a level that permits release of the property and termination of the license.

\section{SAFSTOR}

SAFSTOR is a delayed DECON. A nuclear facility is maintained and monitored in a condition that allows the radioactivity to decay; afterwards it is dismantled.

\section{ENTOMB}

Radioactive contaminants are encased in a structurally sound material, such as concrete, and appropriately maintained and monitored until the radioactivity decays to a level permitting release of the property.

The US NRC requires that the decommissioning of a facility be completed within 60 years, whatever the option or combination of options is taken. On the other hand, the strategy for most UK reactors involves deferrals of up to 100 years, until the radioactivity decays to a level that permits direct handling or removal work.

Of the above options, DECON best matches the concept of "complete dismantlement within ten years” called out in the 1994 Agreed Framework.

\subsection{Decommissioning the 5MWe Reactor}

Since the 5MWe reactor is a graphite moderator type and is known to be modeled after the Calder Hall reactors in the UK, it would be beneficial to review the status of Magnox or graphite reactor decommissioning. There are more than 100 graphite reactors, experimental as well as plutonium production reactors, worldwide. Most of the older graphite reactors are already shut down and waiting to be decommissioned. While decommissioning nuclear reactors, about $99 \%$ of the radioactivity is safely contained in the fuel, which is withdrawn from the reactor following permanent shutdown. Besides surface contamination of the plant, the remaining radioactivity is from structural and piping materials, steels, and concrete that have been exposed to neutrons. In Gas Cooled Reactors (GCRs), a large amount of graphite, used as a neutron moderator and reflector, also becomes radioactive.

\footnotetext{
${ }^{17}$ IAEA, decommissioning of Nuclear Fuel Cycle Facilities, Safety Standards Series, No. WS-G-2.2, 1991, Vienna, Austria.
} 


\subsubsection{Nuclear Graphite Waste}

A typical graphite-moderated reactor contains a few thousand tons of "nuclear-grade" graphite $^{18}$ to moderate and reflect neutrons during reactor operation. The $5 \mathrm{MWe}$ reactor has 600 metric tons of graphite (see Table 2). Graphite has different characteristics than other radioactive waste due to its physical and chemical properties and radioactive content. Waste graphite contains tritium, C-14, corrosion/activation products (Cl-36, Co-57, Co-60, Mn-54, Ni-59, Ni-63, Na-22), fission products (Cs-134, Cs-137, Sr-90, Eu-152, Eu-154, Eu-155, Ce-144), and small amounts of uranium and transuranium elements (Pu-238, Pu-239, Am-241, Am-243).

Carbon-14 (half life: 5730 years) is usually the dominant contributor to the graphite activity. Fission products and transuranium elements exist in the graphite of reactors that have experienced fuel failure. Activation products arise from trace-level impurities. Chlorine-36 (half life: 300,000 years), the activated residual chlorine from graphite purification, is another contaminant of importance due to both its long half life and poor retardation by geologic medium. Radioactivity of graphite depends on the type of graphite reactor, extent of fuel failure, impurities or residues left at graphite manufacture, and time of operation.

As it exists, graphite would seem to meet most of the general disposal requirements for a solid radioactive waste form, since graphite keeps most of its good mechanical properties after many years of irradiation. It is relatively insoluble and not chemically reactive. However, studies evaluating the radioactivity of graphite and other detailed characteristics show that the graphite from nuclear reactors cannot be accepted "as-is" by existing disposal sites. Special treatment is required to increase its resistance to leaching and to remove specific radionuclide content. Thus, countries that have dismantled GCRs just store the graphite that is removed. ${ }^{19}$ Various research and development is underway to increase the retention capacity of radioactive isotopes contained in graphite, to pack more volume of graphite in a waste package, and to study the behavior of graphite in contact with cement or concrete.

\subsubsection{International Status of Graphite Reactor Decommissioning}

Most GCRs built in the era of nuclear introduction were shut down in the 1980s. Before decommissioning began, or even before the decommissioning planning phase, owners or stakeholders of some of the reactors seemed to have iterated through many reviews to set up optimized strategies considering technical, safety, and, consequently, economic factors. The decommissioning plans and experiences of several countries with GCRs were reviewed (details are in Appendix I). Common findings include the following:

\footnotetext{
${ }^{18}$ According to the IAEA Model Additional Protocol (InfCirc 540, corrected), "nuclear grade” graphite has "a purity level better than 5 parts per million boron equivalent and a density greater than $1.50 \mathrm{~g} / \mathrm{cm}^{3}$."

${ }^{19}$ Countries having large volumes of radioactive graphite are UK with 60,000 metric tons, the former Soviet Union with 50,000 metric tons, and France and the US with a similar amount.
} 
- they spend long lead times, usually more than 10 years, before setting up a decommissioning plan,

- the decommissioning phase before reaching SAFSTOR takes 15 to 20 years, and

- decommissioning requires waste management facilities for packaging, storage and disposal.

\subsubsection{Cost}

According to a report by the Nuclear Energy Agency of the Organisation for Economic Co-operation and Development (OECD/NEA), ${ }^{20}$ the cost of decommissioning depends upon the type of reactor (see Table 4).

Table 4. Decommissioning Cost for Selected Reactor Types

\begin{tabular}{|l|r|}
\hline Type & USD/kWe \\
\hline (most) western PWR & $200-500$ \\
\hline VVER & $\sim 330$ \\
\hline BWR & $300-550$ \\
\hline CANDU & $270-430$ \\
\hline UK Magnox & $\leq 2,600$ \\
\hline Tokai-1 $^{21}$ & $\leq 4,700$ \\
\hline
\end{tabular}

GCRs show much higher cost due to the greater amount of radioactive material involved. The estimate for Tokai-1, the only Japanese Magnox reactor, also includes the estimated cost for developing a disposal site.

\subsubsection{Decommissioning of Key Elements}

\subsubsection{Spent Fuel}

\section{Defueling and canning requirements}

Once it is decided to shut down the 5MWe reactor, the fuel would be removed (the reactor would be "defueled”) according to a decommissioning plan. Areas near the reactor, especially the spent fuel handling areas, are first decontaminated to facilitate defueling. The radiological situation of the reactor may be characterized, which would take several years, either before or at the same time as defueling.

The US and the DPRK agreed in 1994 to dispose of the spent fuel from the 5MWe reactor without reprocessing it in the DPRK. The Six Party Talks may lead to a similar

\footnotetext{
${ }^{20}$ OECD/NEA, The Economics of Nuclear Fuel Cycle, NEA/EFC/DOC(93)1, Paris, June 1993.

${ }^{21}$ World Nuclear Association, Decommissioning Activities: Tokai-1, http://www.worldnuclear.org/wgs/decom.
} 
decision on spent fuel, i.e., to remove it from the DPRK. What is not clear is how long it would take before the fuel could be shipped and reprocessed. Magnox-type spent fuel is not easily stored for extended time, even with carefully monitored, inert dry storage. ${ }^{22}$

If the eventual destination of the spent fuel is determined promptly, the spent fuel may be stored in canisters for a relatively short period. Although this will not require long-lasting canisters, much effort will be given to decontaminate the fuel and the surroundings before starting the canning process. Since the preparation itself may take years, ensuring the safety of the stored spent fuel during preparation for shipping is essential.

If the situation requires a longer period of time for storing spent fuel before reprocessing, then the spent fuel will have to be placed in long-lasting canisters following a similar procedure that was taken after the Agreed Framework in 1994. Canning at that time took about five years, due to complications from contamination in the storage area and the lack of proper equipment.

International practices for the regular transport of Magnox spent fuel from one country to another for reprocessing (e.g., from Japan’s Tokai-1 reactor to the UK, or from Italy's Latina reactor to the UK) should be considered to determine the availability and capacity of packaging and transportation and their technical applicability to the DPRK case.

\section{HLW, storage and disposal}

Countries with commercial reprocessing facilities receive spent fuel from their customer countries and return the vitrified HLW to the country of origin, i.e., the customer countries. Applying the experience of Eurochemic reprocessing plant to the DPRK case, reprocessing the DPRK's 16,000 spent fuel elements from the 5MWe reactor will result in about 27 cubic meters of high-level liquid waste. This HLW will be vitrified into glass blocks weighing 37 metric tons in 260 stainless steel containers. These stainless steel containers have to be returned to the DPRK. The DPRK will receive and store 260 stainless steel containers in a facility until a disposal repository is operational.

There are two generic interim storage options for the containers of vitrified high-level waste: air cooled and water cooled. The air storage option is typical of that in use at Marcoule, France, and at Rokkasho-mura, Japan. The storage facility requires a ventilation system to keep the glass in the waste container and concrete structures at safe temperatures. The time for the interim storage phase depends upon availability of a repository and the heat and radioactivity loads that the repository can accept. Whether air cooled or water cooled, a facility is needed to store the 260 stainless steel containers for about 30 to 50 years before they are sent to a disposal site. The capacity of the storage facility should be about 400 containers to accommodate the containers from the vitrification of the liquid HLW that may already exist in the site. This topic is covered later in section 3.3.2.1.

Although the HLW from the 5MWe reactor is only about one tenth as radioactive as the HLW from a CANDU reactor, the time required for it to decay to a safe level is still

\footnotetext{
${ }^{22}$ (UK) Radioactive Waste Management Advisory Committee's Advice to Ministers on: The Radioactive Waste Implications of Reprocessing (November 2000), Annex 4: Dry Storage and Disposal of Magnox Spent Fuel, http://www.defra.gov.uk/rwmac/reports/reprocess/16.htm.
} 
several tens of thousands of years. Thus for HLW disposal, a deep and stable geological formation is required to ensure long-term safety.

Thorough characterization of a candidate site is expensive and time-consuming. Internationally, the US is the most advanced country in developing a geological repository for HLW. The Yucca Mountain repository in Nevada, which has been explored for many years, recently obtained congressional approval for HLW. The Yucca Mountain repository is considered to be the fruit of the Nuclear Waste Policy Act of 1980. Japan, Canada, France, and the UK have either passed legislation for the procedures to investigate and acquire sites for HLW repositories, or established the organization(s) to undertake long-term procedures for HLW disposal.

\section{Detailed stages for spent fuel management}

The details of spent fuel treatment, from initial defueling to final disposal, can be grouped with respect to flow and activities as follows:

- Defueling stage Defueling, including decontamination of necessary surroundings

Decontaminating the spent fuel storage pool

Manufacturing canisters for interim storage

Canning spent fuel for interim storage

- Reprocessing Manufacturing or leasing transportation casks/canisters stage

Transferring spent fuel into the transportation casks

Transporting the spent fuel casks abroad

Reprocessing the spent fuel, including vitrifying liquid HLW

- HLW storage Transporting vitrified HLW back to the DPRK stage

Constructing and operating a storage facility for vitrified HLW

- HLW disposal Planning the HLW disposal system stage

Investigating sites for a HLW repository

Characterizing sites and applying for license

Constructing and operating the HLW repository

In reality, the detailed stages listed above may be spread over a wide range of milestones. If properly scheduled and agreed upon, the defueling and reprocessing stages may take no more than ten years. The HLW storage stage lasts for several decades, and the HLW disposal stage is even longer. 


\section{Costs for stages}

It is difficult to estimate cost for each stage in the DPRK case. Comparisons of individual cost estimates for decommissioning a specific facility or activity show relatively large variations. A standardized costing method ${ }^{23}$ has been sought for decommissioning internationally, which can be applied to the DPRK case in the future.

The cost of defueling can be estimated based on the experience from the spent fuel canning that was done in the DPRK in the 1990s. The reprocessing stage may be difficult to estimate using published cost data, since those figures are based on long-term contracts between commercial reprocessing companies and customers, and they assume massive amounts of material. The cost of the HLW disposal stage is the most difficult to estimate, since it occurs over a very long time.

Nevertheless, it may be possible to get a rough estimate of costs for the spent fueltreating stages for the DPRK case by applying unit cost figures for the back-end of the fuel cycle "Reprocessing Option" given by OECD/NEA for light water reactors. ${ }^{24}$ In Table 5, the estimated cost is attained by scaling the OECD/NEA reference unit price to $100 \mathrm{tU}$ of spent fuel. ${ }^{25}$

Table 5. Spent Fuel Cost based on LWR Fuel Cycle Unit Prices

\begin{tabular}{|l|l|l|l|}
\hline & $\begin{array}{l}\text { Reference } \\
\text { Unit Price } \\
\text { (USD / kgU) }\end{array}$ & $\begin{array}{l}\text { Uncertainty } \\
\text { (range in unit price, } \\
\text { USD / kgU) }\end{array}$ & $\begin{array}{l}\text { Estimated Cost } \\
\text { (USD) }\end{array}$ \\
\hline $\begin{array}{l}\text { Transporting spent } \\
\text { fuel }\end{array}$ & 50 & $20-80$ & $5,000,000$ \\
\hline $\begin{array}{l}\text { Reprocessing spent } \\
\text { fuel }\end{array}$ & 720 & $540-720$ & $72,000,000$ \\
\hline Disposing HLW & 90 & $90-580$ & $9,000,000$ \\
\hline
\end{tabular}

The OECD/NEA estimates are based on transportation within Europe; estimates for transportation between continents will likely be much greater. It is assumed that transportation casks are already available. If a specific design for the transportation cask is needed for the DPRK case, additional cost must be considered.

\footnotetext{
${ }^{23}$ OECD/NEA, A Proposed Standardised List of Items for Costing Purposes in the Decommissioning of Nuclear Installations, Interim Technical Document, OECD/NEA-IAEA-EC, Paris, 1999, available at http://www.nea.fr/html/rwm/reports/1999/costlist.pdf.

${ }^{24}$ OECD/NEA, “The Economics of the Nuclear Fuel Cycle,” NEA EFC DOC (93)1, June 1993, Paris, available at http://www.nea.fr/html/ndd/reports/efc/EFC-complete.pdf.

${ }^{25}$ All prices were money values as of early 1991, and assume a 1:1 exchange rate at that time between European Currency Units (ECU) and USD. Spent fuel cost seems to be independent of corrosion state of fuel elements.
} 
Spent fuel reprocessing includes the disposal cost for LLW and ILW, the vitrification cost for HLW, and the interim storage cost of the vitrified waste until shipped back to the country of origin.

As seen in Table 5, this cost has a wide range of uncertainty: up to 6 times the reference unit price. Moreover, there are additional uncertainties because disposal of HLW has so far never been done, and it will occur in several decades later. Also, if a repository is to be constructed only for this amount of HLW, the basic investment for site characterization and construction will increase the unit price unpredictably.

\subsubsection{Graphite Moderator and Reflector}

The total amount of graphite that would need to be removed from the 5MWe reactor after defueling is reported to be 600 metric tons, or about 400 cubic meters, in approximately equal amounts from the moderator (reactor core) and reflector (surrounding the reactor core).

The graphite is in the form of blocks, usually stacked in several layers. The graphite blocks may be held together by steel restraint bands and interlaced by thermocouple wires and neutron flux measuring detectors. To remove graphite blocks from the reactor vessel, custom remote handling equipment must be used for cutting, clamping, and grabbing steel wires, plates, and graphite blocks. Designing and manufacturing the necessary remote operation equipment can take about two years, assuming a full knowledge of reactor core design specifications. This is normally done during the initial phase of decommissioning.

Since the graphite blocks may have various activity levels and different contaminations, sorting them based on their activity levels may help reduce the amount of graphite requiring the greatest decontamination effort.

Graphite blocks removed from the GCRs of the UK, France, and other countries are encapsulated in concrete and placed in specially designed storage buildings. They must be stored in that way until proper repositories, conforming to regulations, can be constructed.

Besides the absence of proper repositories, waste-form stabilization is another issue. There have been many studies on how to prevent or reduce radionuclide leaching from graphite during storage. Metallization of the graphite surface using several methods has been investigated as one promising option for efficient leaching resistance. No method, however, has been selected for mass application to graphite stabilization.

For the time being, graphite blocks removed from the 5MWe reactor should follow the same procedure as in the UK and other countries: packaging and storing. Specially designed containers will be needed to hold the graphite. Both a packaging building and a storage building should be built near the reactor site. The storage building will have to be under regular surveillance and monitoring to detect radionuclide leaks.

\subsubsection{Reactor Vessel, Steel Structures, and Concrete}

Steel structures, such as the pressure vessel and thermal shield, are radioactive, having been activated by exposure to neutrons during normal reactor operation. Activation 
products include the radioisotopes ${ }^{60} \mathrm{Co},{ }^{55} \mathrm{Fe},{ }^{59} \mathrm{Ni},{ }^{63} \mathrm{Ni}$, and ${ }^{94} \mathrm{Nb}$. Concrete surrounding the reactor vessel also undergoes neutron activation, and contains the activation products ${ }^{3} \mathrm{H},{ }^{14} \mathrm{C},{ }^{36} \mathrm{Cl},{ }^{152} \mathrm{Eu}$, and ${ }^{154} \mathrm{Eu}$. Because some of these activation products have long halflives, the steel structures and concrete cannot generally be treated as LLW.

As activation depends on the location of the material and its distance from the core, a detailed survey of the content of each radionuclide at different depths and locations should be performed. With the precise data of radioactivity distribution on and in the steel structures and concrete materials, one may set up a strategy to reduce the volume of ILW. An estimation study of decommissioning a GCR ${ }^{26}$ shows that about $30 \%$ of the steel structure could be released through measurement and decontamination and another $30 \%$ was packaged for ILW. Similarly, 97\% of concrete could be released free.

The 5MWe reactor will generate about 300 metric tons of steel (excluding pipes that were not subject to activation) and several thousand tons of concrete bioshield as waste. To reduce the volume of ILW, a sophisticated facility to segregate the waste according to its activity content should be provided. If this facility is equipped and operates as shown in the reference, one may reduce the intermediate-level steel waste to about $30 \%$ and concrete waste to about $3 \%$.

By any means, a repository for ILW to accommodate 100 metric tons of steel and several hundred tons of concrete should be available. An interim storage facility for intermediatelevel steel and concrete waste should be operating until a long-term repository is available. A waste packaging method for long-term storage should also be provided.

\subsection{Decommissioning the Radiochemical Laboratory}

\subsubsection{International Precedents for Reprocessing Facility Decommissioning}

Most reprocessing facilities built during the early period of nuclear introduction have been shut down, and some of them are still undergoing decommissioning. For some nuclear reactors, such as GCRs, deferring the final dismantling may be beneficial in reducing the cost related to radiation risks. In the case of a reprocessing plant, deferring decommissioning does not help with respect to radiation hazard reduction.

Through international programs set up by OECD/NEA and IAEA, the countries with reprocessing facilities have shared information, experience, and personnel and have cooperated in the decommissioning of reprocessing facilities. The Eurochemic reprocessing plant is a good example of international cooperation. Although many differences exist, the Eurochemic plant is reported to be a model for the DPRK's Radiochemical Laboratory. Appendix II reviews the Eurochemic experience and also considers two decommissioning cases for French reprocessing plants.

\footnotetext{
${ }^{26}$ R.J. Printz, U.Quade, \& J. Wahl, Packaging Requirements for Graphite and Carbon from the Decommissioning of the AVR in consideration of the German Final Disposal Regulations: Technology for gas cooled reactor decommissioning, fuel storage, and waste disposal. Proceedings of Technical Committee meeting held in Jurich, Germany, pp 275-285. IAEA, 8-10 September, 1997.
} 


\subsubsection{Decommissioning of Key Elements}

\subsubsection{Liquid High-Level Waste}

\section{Characteristics}

The volume of liquid waste from reprocessing depends on the mass of spent fuel, whether it is low-or high-burnup fuel. However, the amount of radioactive material (fission products and actinides, components of high-level waste, HLW) contained in the spent fuel, and therefore also in the liquid waste, depends mostly upon burnup. To obtain weapons grade plutonium, the DPRK operated the 5MWe reactor for a very low burnup, averaging $635 \mathrm{MWD} / \mathrm{tU}$, so the fuel contains a relatively small portion of fission products and actinides. Once vitrified, the liquid HLW from reprocessing the 5MWe reactor fuel may result in much smaller solid volume than what would result from waste vitrification associated with high burnup fuel.

Nothing is known about the status of the liquid HLW in the DPRK. To remove the traces of their past nuclear activities, the DPRK might have mixed the liquid HLW with other type of waste or with something else, which will not only cause difficulties in reducing volume as a preparatory step for vitrification, it may also be totally impossible to segregate the liquid HLW from the mixed state. Thus, although the burnup of the spent fuel is quite low and the resulting volume of vitrified waste would be relatively small, it would be safe to assume that the liquid HLW in the DPRK contains almost the same amount of radioactive material as does the liquid HLW from high burnup fuel.

\section{Reducing the volume}

The liquid HLW, as listed in Table 3, has to be immobilized for the ease and safety of long-term storage and final disposal in a repository. Immobilization is done by vitrifying concentrated liquid HLW. If a process line is provided to recover nitric acid and concentrate the HLW as is stored now, the waste volume can be reduced to less than onetenth of the original volume.

\section{Shipping the liquid HLW}

Liquid HLW would need to be shipped in 200-liter drums with good shielding, leak tightness, impact- and fire-proved. If no volume concentration is done, the liquid HLW will require 2,500 drums. Usually reprocessing facilities are co-located with vitrification facilities, removing the chances of accidents occurring during transportation.

Eurochemic, however, shipped about 50 cubic meters of HLW to a vitrification facility in Germany, PAMELA, in the 1980s.

\section{Vitrification}

As with the case of Eurochemic, the vitrification of the HLW-concentrated during the course of reprocessing 100 metric tons of natural uranium fuel-will result in 260 stainless steel containers filled with 37 metric tons of glass. 


\section{Shipping back and storing the vitrified HLW}

The 260 stainless steel containers will be shipped back to the DPRK, where they must be stored until the final repository is available.

\section{Cost}

Waste volume reduction is a part of the reprocessing process in which a breakdown cost is not readily available. If the large amount of liquid HLW is shipped, it will be a one-ofa-kind experience for which pricing is impossible. If the safety concern of shipping the liquid HLW is comparable to that of spent fuel, the spent fuel case may be referenced. For vitrification, if the Eurochemic case is applied, it will cost about 5.2 million USD. Storage and disposal of this HLW will be done at the same facility for the HLW from reprocessing the spent fuel.

\subsubsection{Liquid Waste from Chemical Decladding}

\section{Characteristics}

The Radiochemical Laboratory in the DPRK is reported to have operated a process to dissolve fuel cladding. In the Eurochemic plant, magnesium cladding was dissolved in sulfuric acid, resulting in three cubic meters of waste solution per metric ton uranium. It is categorized as ILW, for which storage is the only management solution until a specific repository is acquired. In the DPRK case, there would be 300 cubic meters of cladding waste solution after reprocessing 100 metric tons of fuel. To store the waste safely for a relatively long time, the solution has to be immobilized by applying a solidification agent.

\section{Solidification methods}

Bitumen (asphalt) was used in the Eurochemic plant for immobilizing the chemical decladding waste. Bitumen is highly leach-resistant, has a low operating temperature, and possesses a good degree of plasticity. At its operating temperature, 99\% of the water evaporates, resulting in a volume reduction of up to fivefold compared with conventional cementing techniques. Although some technical improvements have been added to the bituminization process, inherent drawbacks of the bitumen are its potential fire hazard and weak radiation resistance, resulting in the release of hydrogen gas. Typical bitumen products contain 40 to 60 weight percent waste solids.

Immobilization of radioactive waste by incorporating it into hydraulic cement has been practiced worldwide for many years. It does not present a fire hazard and has good radiation resistance. Its drawbacks are low leach-resistance and low content of waste solids. The addition of sodium silicates or polymers has been studied and applied in other commercial fields to improve its characteristics.

Glass is a good medium to contain chemical decladding waste. Glass has high radiation resistance and leach resistance. It does not present a fire hazard. Vitrification, the process of embedding the waste in glass, is expensive, and therefore is usually applied only to the solidification of HLW, rather than ILW. 
Solidification of a type of radioactive waste with a specific medium requires thorough study of possible interactions between the waste and the medium. Selecting the method to apply and developing the process takes a long time before an actual process is put into operation.

\section{Costs, storage and disposal of solidified chemical decladding waste}

It is difficult to estimate how much solidified volume of chemical decladding waste will result from each solidification method. Since Eurochemic had combined various kinds of chemical decladding waste for solidification, segregating the bituminized volume for the magnesium decladding waste seems to be impossible. From the estimated mass of the magnesium involved $^{27}$ and with proper chemical reactions assumed, one could calculate the volume of solidified chemical decladding waste.

According to a report in 1976, costs for Eurochemic bituminization plant, including the storage of the solidified wastes, were as follows:

- Treatment installation (Eurobitume):

basic investments

modifications, cold tests

operation

- Storage

basic investments
USD 5M

USD $0.37 \mathrm{M}$

USD 2,500-3,000 per $\mathrm{m}^{3}$ of treated effluents

USD 3.25M, including the reception station for waste produced outside the bituminization plant, handling equipment, and two storage bunkers with capacity of 10,000-12,000 drums.

For storage and disposal, the solidified waste from chemical decladding may share the same facilities with other waste streams, such as the graphite, steel, and concrete from the dismantling of the 5MWe reactor.

\subsubsection{Steels and Concrete}

It is foreseeable that the decommissioning of the Radiochemical Laboratory and its related buildings will result in a large amount of steel and concrete waste. Most of the steel and concrete wastes from a reprocessing facility involve surface contamination, rather than activated bulk material. The contamination is largely high alpha radioactivity, which must be disposed of in a deep geological formation like the HLW.

The similarity of the Radiochemical Laboratory and the Eurochemic plant enables us to estimate the volume of materials to treat from the Radiochemical Laboratory. The Radiochemical Laboratory should produce roughly one-half to two-thirds as much solid waste: 500 to 1,000 metric tons of steel/metal and 16,000 to 24,000 metric tons of

\footnotetext{
${ }^{27}$ Each fuel element is clad with about $100 \mathrm{~g}$ magnesium. Considering a total of 16,000 spent fuel elements, the mass of magnesium involved in chemical decladding is about 1.6 metric tons.
} 
concrete (6,000 to 9,000 cubic meters). Assuming the same level of decontamination technology as was available for the Eurochemic plant, much of it can be released without any restriction: about $66 \%$ of metal (330 to 660 metric tons) and $93 \%$ of concrete (roughly 15,000 to 23,000 metric tons; 5,600 to 8,400 cubic meters). The rest will require special consideration for storage or disposal, and some portions of them will need to be disposed of as HLW.

\subsection{Basic Schemes for Decommissioning}

The decommissioning schemes described in the following sections and depicted in the accompanying figures are based upon the following assumptions.

- All the tasks required for decommissioning are performed in harmony with each other. The proper investment for those activities and infrastructure that require long lead times is done on time.

- The spent fuel withdrawn from the reactor is shipped to another country for reprocessing, while the vitrified HLW is then shipped back to the DPRK.

- Liquid HLW already generated by reprocessing in the DPRK will be shipped to another country for vitrification, and then returned to the DPRK in vitrified form.

- Storage and final disposal of LLW, ILW, and vitrified HLW will be done in the DPRK.

Economic feasibility is not taken into consideration.

\subsubsection{Spent Fuel and the 5MWe Reactor}

Figure 5 shows a decommissioning scheme for treating the spent fuel from the $5 \mathrm{MWe}$ reactor. In this scheme, a key issue will be the timely shipping of the spent fuel out of the country, provided that a place to reprocess the spent fuel is secured. The vitrified HLW from both the reprocessing of the spent fuel and the vitrification of the liquid HLW will require interim storage upon return to the DPRK. Eventually a small disposal repository for the HLW, with the capacity of about 400 disposal casks of HLW, will have to be provided as the final step of the scheme.

Figure 6 shows how the solid wastes are categorized and how much of each type of waste will be generated from dismantling the 5MWe reactor. Some metal and concrete waste containing long-lived radionuclides should follow the same path as that for graphite. Special packaging methods have to be sought for long-term leak-free waste forms for the graphite as well as for a relatively small amount of metal and concrete. A storage facility will serve until the disposal site for this waste is found. 
Figure 5. Schematic flow for spent fuel: from defueling the 5WMe reactor to disposal of HLW

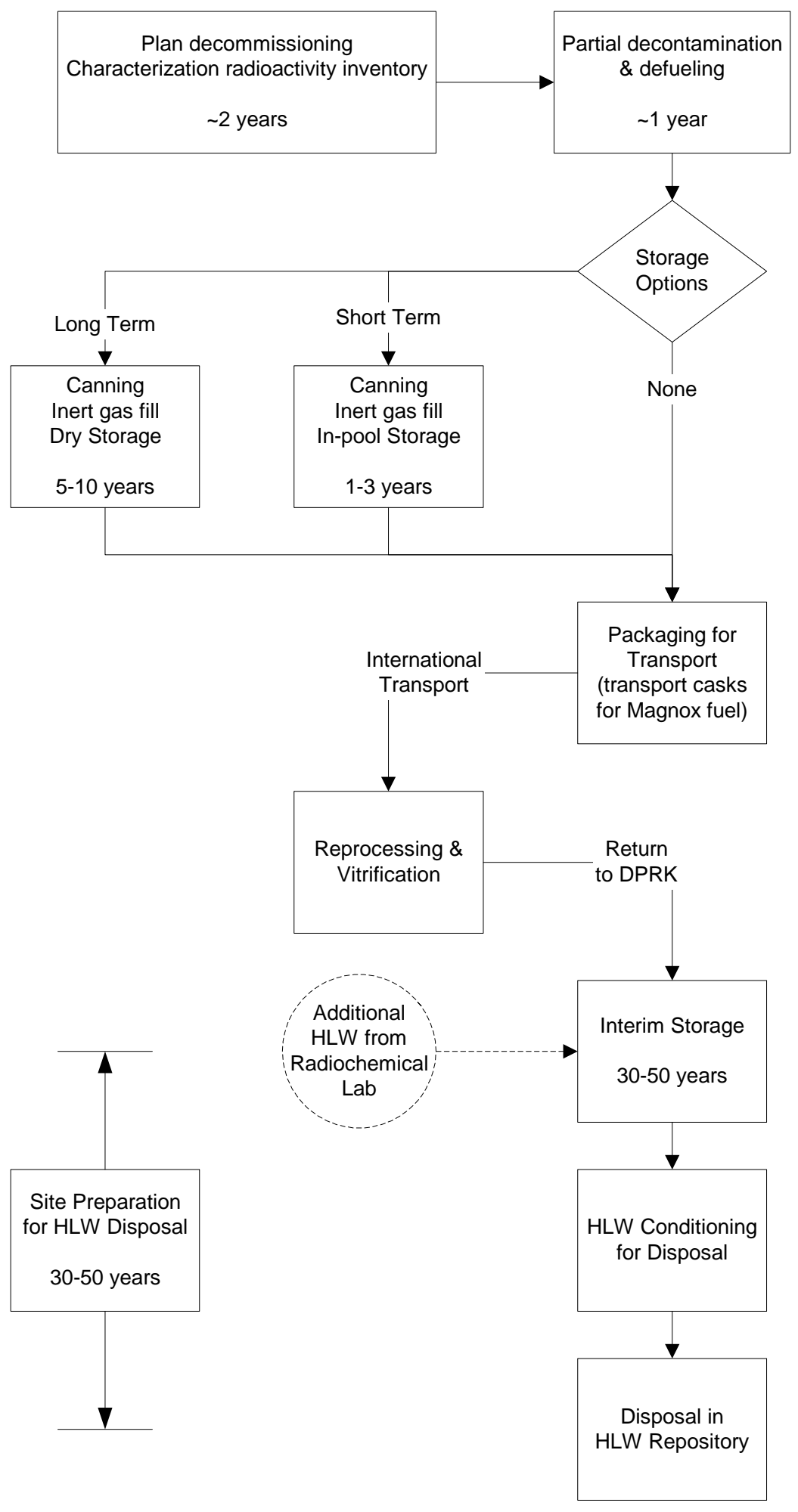


Figure 6. Schematic flow for solid wastes from dismantling the 5WMe reactor

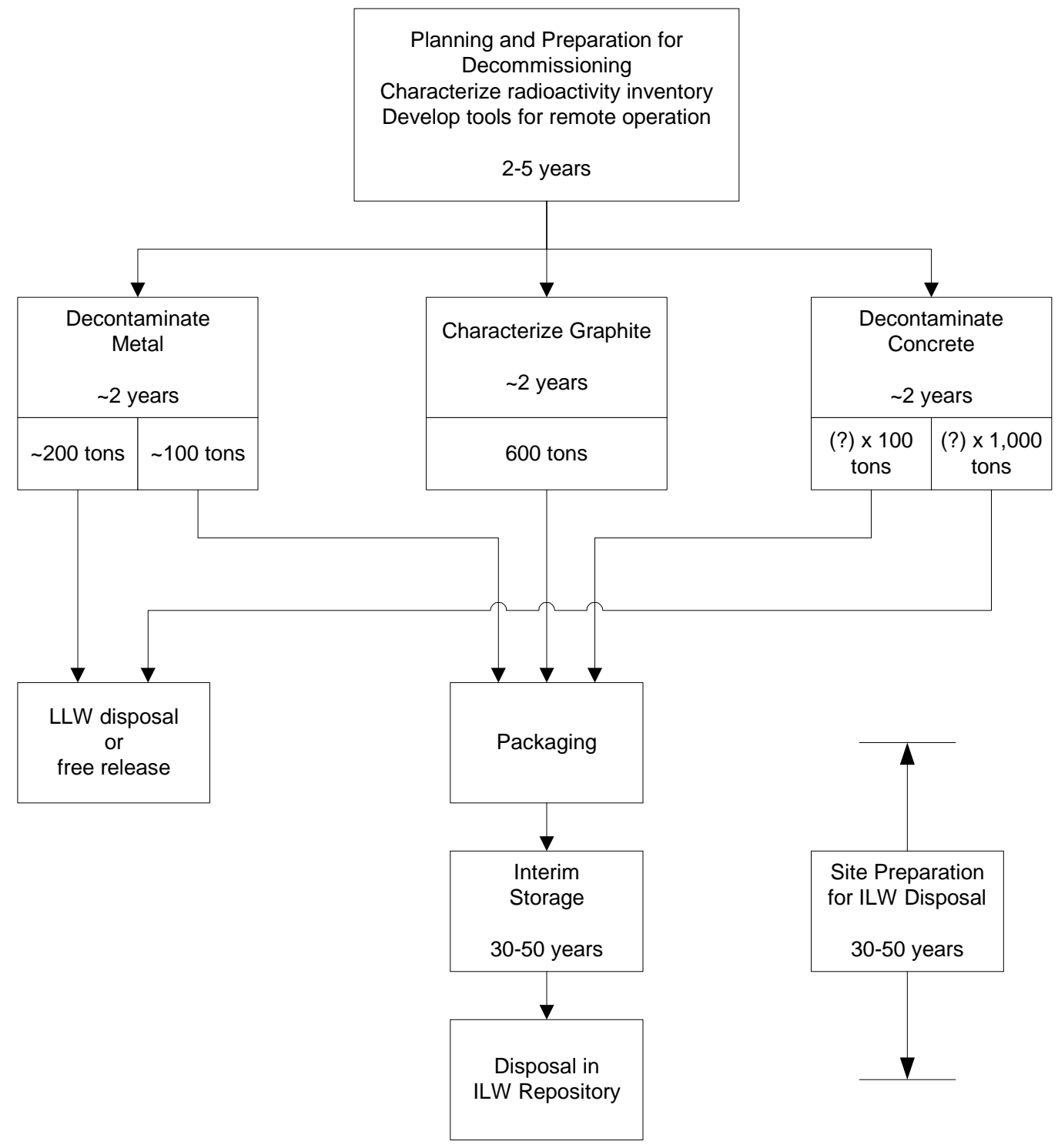




\section{Liquid HLW, Chemical Decladding Waste, and the Radiochemical Laboratory}

Liquid HLW will follow the scheme in Figure 7. This assumes that the required preplanning has been done before deploying an HLW volume reduction facility. Analysis of this HLW is so critical in revealing the past history of reprocessing in the Radiochemical Laboratory that may take longer than 1-2 years. The current impasse with regard to waste treatment will be whether we have enough experience in long-distance transport of HLW in liquid form. If the volume matters, a process line for volume reduction may have to be added to the existing facility, which may delay dismantling the Radiochemical Laboratory. Two years (shown in the figure) is an aggressively optimistic estimate for incorporating a volume reduction facility, but possible. Once the liquid HLW is vitrified, it will be stored in the interim HLW storage facility with the reprocessed spent fuel HLW until a disposal repository is available.

Figure 7. Schematic flow for liquid HLW stored at the Radiochemical Laboratory

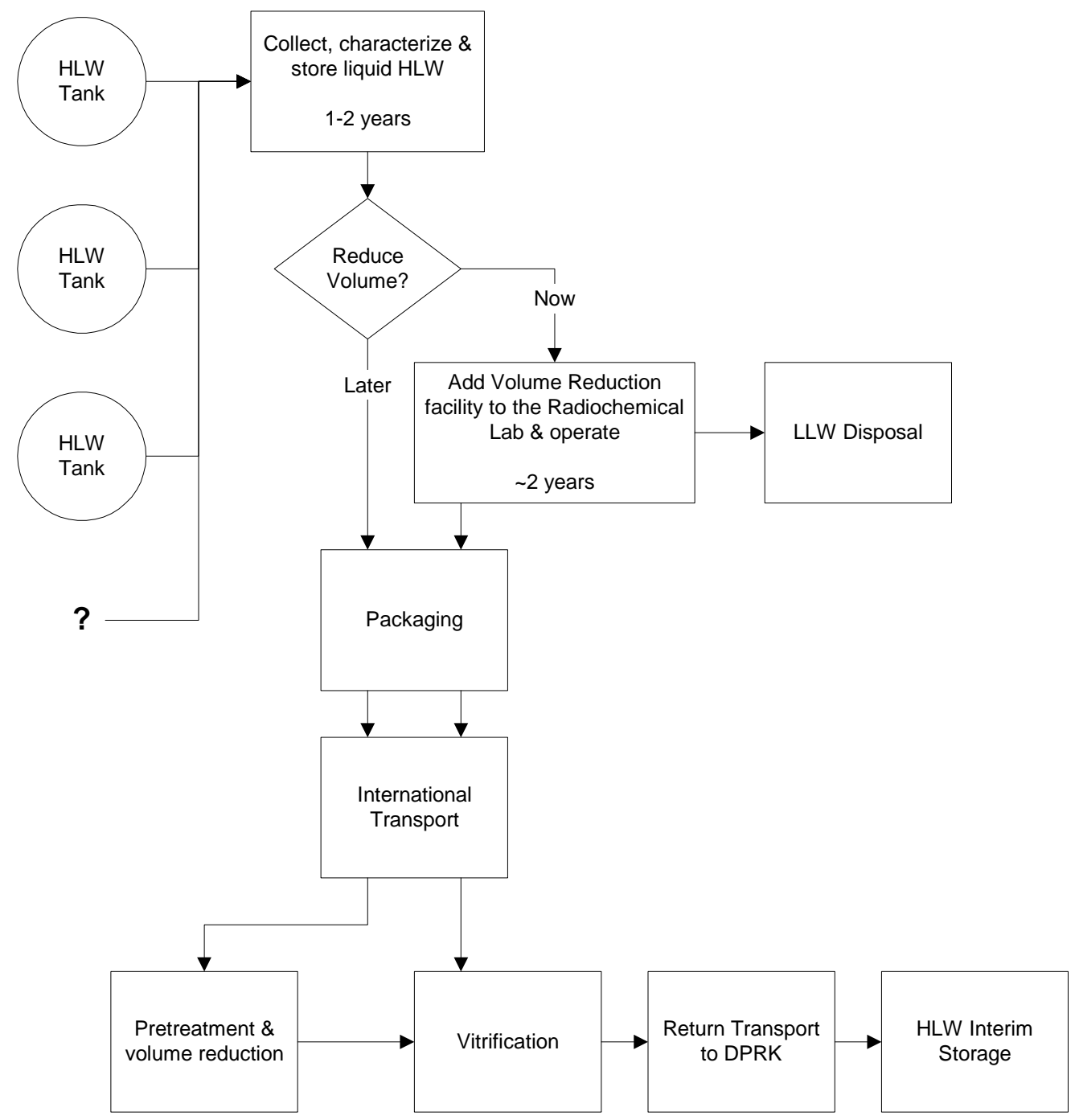


The chemical decladding waste should be solidified for interim storage and final disposal as depicted in Figure 8. This will take a somewhat long time in characterizing the waste and selecting and constructing the solidification process.

\section{Figure 8. Schematic flow for Chemical Decladding Waste stored at the Radiochemical Laboratory}

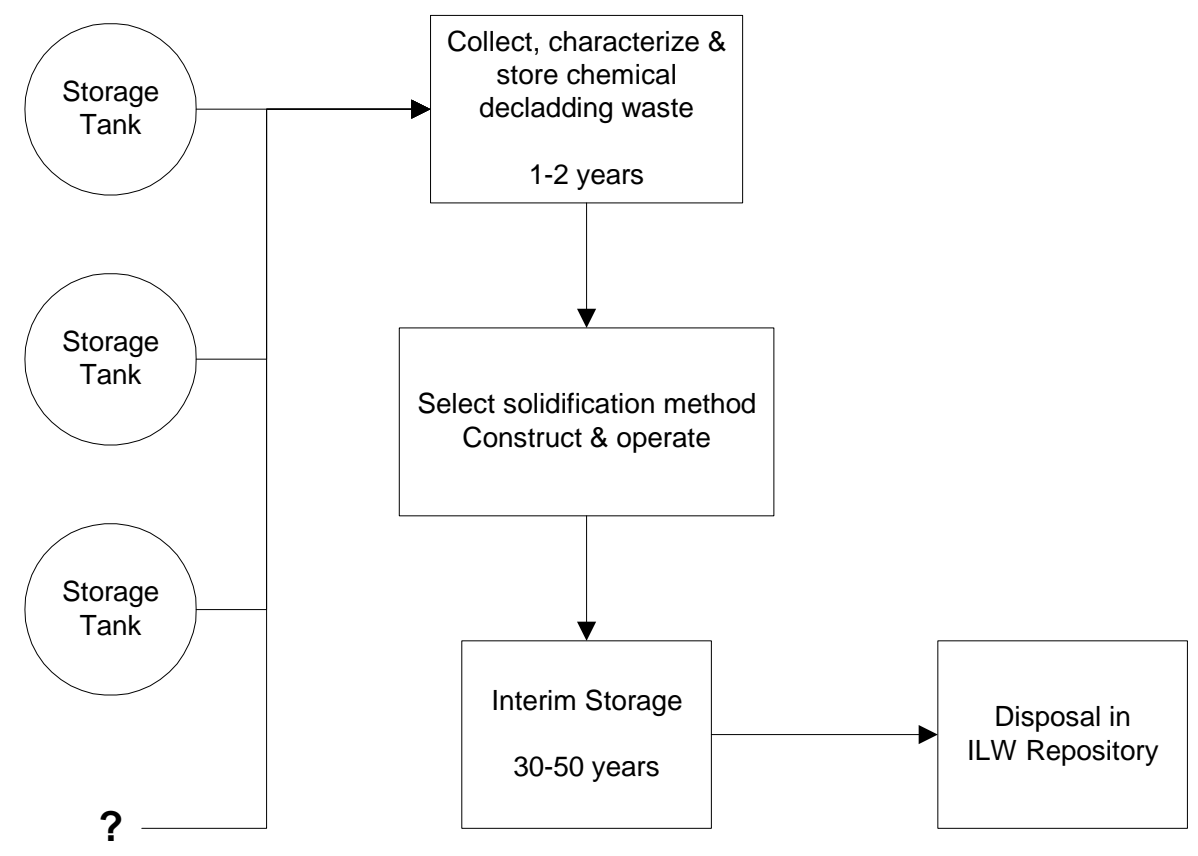

Figure 9 shows the disposition of solid waste from decommissioning the Radiochemical Laboratory. After surface decontamination, most of the concrete and metal may be released free or as LLW. Several hundred tons of concrete and metal remain as intermediate waste due to high alpha radioactivity after decontamination. A relatively small amount with very high activity of alpha emitting radionuclides may have to be treated along with HLW. 
Figure 9. Schematic flow for solid wastes from the Radiochemical Laboratory

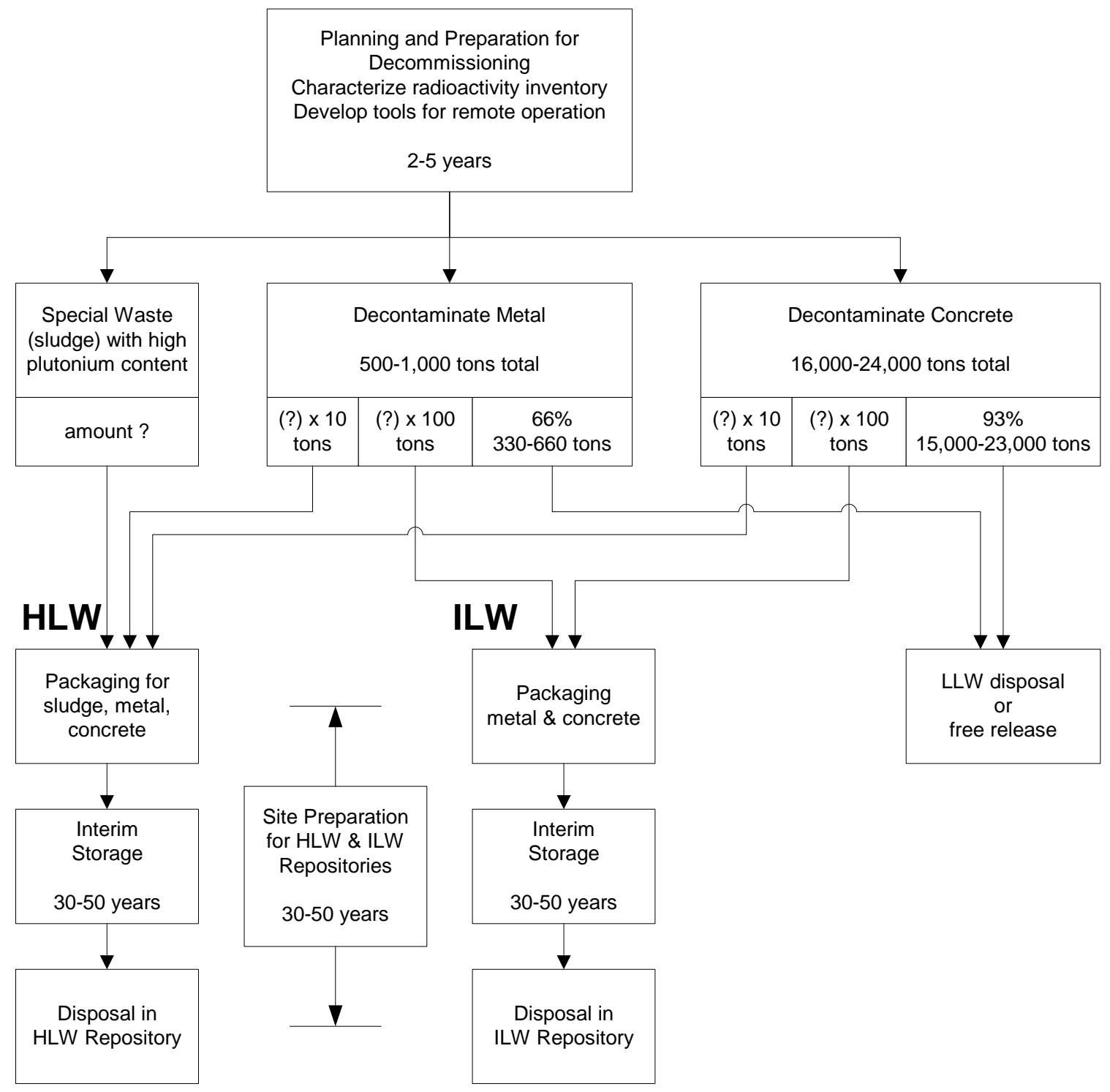

\subsubsection{Facilities Required for Waste Management in the DPRK}

Reviewing the basic schemes shown in Figures 5 through 9, one may realize that operating and dismantling those facilities call for a wide range of activities, including treatment, packaging, storage, and disposal. Table 6 lists the facilities needed to manage the waste that results from decommissioning the 5MWe reactor and the Radiochemical Laboratory.

In the initial phase of decommissioning, the processes of decontamination, canning, and packaging require dedicated facilities and the development of tools and package forms. Canning tools used during 1994-1996 may not exist anymore. Facility operation should be supported by precise analytical capability. 
Table 6. Facilities needed to manage the wastes from decommissioning the $5 \mathrm{WMe}$ reactor and the Radiochemical Laboratory

\begin{tabular}{|c|c|c|c|c|c|}
\hline Facility & Location & Application & \multicolumn{3}{|c|}{ Capacity } \\
\hline \multicolumn{6}{|l|}{ Immediate Needs } \\
\hline Canning Station & $\begin{array}{l}\text { at the } 5 \mathrm{MWe} \\
\text { reactor }\end{array}$ & $\begin{array}{l}\text { Spent fuel is canned; cans filled } \\
\text { with inert gas } \\
\text { Requires decontamination } \\
\text { before canning; special tools } \\
\text { for broken fuel rods; shielding }\end{array}$ & \multicolumn{3}{|c|}{$\begin{array}{l}50 \text { or } 100 \mathrm{tU} \\
(8,000 \text { or } 16,000 \text { fuel elements) }\end{array}$} \\
\hline $\begin{array}{l}\text { Temporary Dry } \\
\text { Storage Pit }\end{array}$ & 5 MWe reactor & $\begin{array}{l}\text { Storage of canned spent fuel } \\
\text { for } 5-10 \text { years }\end{array}$ & \multicolumn{3}{|c|}{50 or $100 \mathrm{tU}$} \\
\hline Packaging Station & 5 MWe reactor & $\begin{array}{l}\text { Canned spent fuel prepared for } \\
\text { overseas transport } \\
\text { Requires transport casks for sper }\end{array}$ & \multicolumn{3}{|c|}{50 or $100 \mathrm{tU}$} \\
\hline Packaging Station & $\begin{array}{l}\text { Radiochemical } \\
\text { Laboratory }\end{array}$ & $\begin{array}{l}\text { Liquid HLW packaged for } \\
\text { overseas transport } \\
\text { Requires transport casks for liqu }\end{array}$ & \multicolumn{3}{|c|}{$\begin{array}{l}250,000 \text { or } 500,000 \text { liters HLW } \\
d H L W\end{array}$} \\
\hline \multicolumn{2}{|l|}{ Mid-Term Needs } & \multicolumn{4}{|c|}{ Requires transport casks for liquid HLW } \\
\hline \multirow[t]{3}{*}{$\begin{array}{l}\text { Decontamination } \\
\text { \& Packaging } \\
\text { Station }\end{array}$} & \multirow[t]{3}{*}{$\begin{array}{l}\text { Yongbyun } \\
\text { Nuclear } \\
\text { Research Center }\end{array}$} & $\begin{array}{l}\text { Metals: } \quad \text { decontaminate } \\
\text { package for ILW storage }\end{array}$ & \multicolumn{3}{|c|}{$\begin{array}{l}300 \text { t from the reactor; } \\
500-1,000 \text { t Radiochemical Lab } \\
\sim 100 \text { t from the reactor; } \\
\text { (?)x100 t Radiochemical Lab }\end{array}$} \\
\hline & & $\begin{array}{l}\text { Concrete: decontaminate } \\
\text { package for ILW storage }\end{array}$ & \multicolumn{3}{|c|}{$\begin{array}{l}\text { (?)x1,000 t from the reactor; } 16- \\
\text { 24,000 t Radiochemical Lab } \\
\text { (?)x100 t from the reactor; } \\
\text { (?)x100 t Radiochemical Lab }\end{array}$} \\
\hline & & $\begin{array}{l}\text { Graphite: } \\
\text { characterize and package } \\
\text { Requires waste package form }\end{array}$ & \multicolumn{3}{|c|}{$600 \mathrm{t}$ from the reactor } \\
\hline $\begin{array}{l}\text { Disposal Site for } \\
\text { LLW }\end{array}$ & DPRK & $\begin{array}{l}\text { LLW from decommissioning } \\
\text { both reactor \& Radiochemical } \\
\text { Lab }\end{array}$ & \multicolumn{3}{|c|}{ depends on the free release limit } \\
\hline \multicolumn{6}{|l|}{ Long-Term Needs } \\
\hline $\begin{array}{l}\text { Interim Storage } \\
\text { Facility for solid } \\
\text { HLW }\end{array}$ & $\begin{array}{l}\text { Yongbyun } \\
\text { Nuclear } \\
\text { Research Center }\end{array}$ & $\begin{array}{l}\text { Store HLW returned from } \\
\text { overseas after vitrification, } \\
\text { including HLW from both the } \\
\text { reprocessed spent fuel and the } \\
\text { existing liquid HLW inventory. } \\
\text { Dry storage requires heat remov }\end{array}$ & \multicolumn{3}{|c|}{$\begin{array}{l}390 \text { HLW canisters } \\
\text { + special waste, metal, and concrete } \\
\text { from the Radiochemical Lab } \\
\text { decommissioning } \\
\text {; storage for } 30-50 \text { years }\end{array}$} \\
\hline \multirow{5}{*}{$\begin{array}{l}\text { Interim Storage } \\
\text { Facility for solid } \\
\text { ILW }\end{array}$} & \multirow{5}{*}{$\begin{array}{l}\text { Yongbyun } \\
\text { Nuclear } \\
\text { Research Center }\end{array}$} & \multirow[b]{2}{*}{ reactor decommissioning } & Metal & Graphite & Concrete \\
\hline & & & $\sim 100 \mathrm{t}$ & $600 \mathrm{t}$ & (?) $\mathrm{x} 100 \mathrm{t}$ \\
\hline & & Chemical decladding & $?$ & -- & -- \\
\hline & & $\begin{array}{l}\text { Radiochemical Lab } \\
\text { decommissioning }\end{array}$ & $\begin{array}{l}\text { (?)x10 } \\
0 \mathrm{t}\end{array}$ & -- & (?)x100 t \\
\hline & & \multicolumn{4}{|c|}{ Requires waste package form; storage for $30-50$ years } \\
\hline $\begin{array}{l}\text { Disposal Site for } \\
\text { HLW }\end{array}$ & DPRK & $\begin{array}{l}\text { for vitrified HLW from } \\
\text { reprocessed spent fuel and } \\
\text { liquid HLW inventory } \\
\text { for special waste from the } \\
\text { Radiochemical Lab } \\
\text { Requires a very long lead time }\end{array}$ & \multicolumn{3}{|c|}{ 390 HLW disposal casks } \\
\hline \multirow{5}{*}{$\begin{array}{l}\text { Disposal Site for } \\
\text { ILW }\end{array}$} & \multirow[t]{5}{*}{ DPRK } & \multirow[b]{2}{*}{ reactor decommissioning } & Metal & Graphite & Concrete \\
\hline & & & $\sim 100 \mathrm{t}$ & $600 \mathrm{t}$ & (?)X100 t \\
\hline & & chemical decladding & $?$ & -- & -- \\
\hline & & $\begin{array}{l}\text { Radiochemical Lab } \\
\text { decommissioning }\end{array}$ & $\begin{array}{l}(?) \times 10 \\
0 \mathrm{t}\end{array}$ & $\begin{array}{ll}- \\
-\end{array}$ & (?)x100 t \\
\hline & & \multicolumn{4}{|l|}{ Requires a long lead time } \\
\hline
\end{tabular}


In the middle phase, interim storage facilities for HLW and ILW must be provided. The length of the storage period may depend on how soon the disposal sites can be acquired, which normally takes 30 to 50 years. A LLW disposal site should already be operating during this phase.

In the final phase, repositories for final disposal of both HLW and ILW are required. 


\section{Strategic Alternatives}

Planning to decommission the nuclear facilities in the DPRK, being limited in this report to the 5MWe reactor and the Radiochemical Laboratory, should be based on two strategic principles.

- Decommissioning for CVID

Decommissioning the two nuclear facilities should adequately answer the proposition of CVID (complete, verifiable, irreversible dismantling). To come as near to CVID as possible, we have to consider all possible technical means. The technical means, however, may also have to be selected according to their effectiveness in revealing past activities.

- Decommissioning for the safety of the environment

A premise for decommissioning is also the safety of the environment. Planning to decommission the two nuclear facilities in accordance with international practices and standards of safety will be persuasive in drawing cooperation not only from the DPRK, but also from other parties.

Many additional factors can also play a role in developing the decommissioning strategy, such as cost and availability of funding, sustainability, and intergenerational equity arguments, stakeholder views, worker radiation health and safety, and others.

\subsection{Fast Track Decommissioning}

If an outcome of the Six Party Talks requires that the reactor and Radiochemical Laboratory be decommissioned as quickly as possible, we need to consider how soon the decommissioning project can be accomplished. For example, the 1994 Agreed Framework had stipulated ten years. Such a "fast track" approach may accept minimum achievement of decommissioning goals, rather than allow for long lead times and adequate investment for infrastructure.

We assume that the spent fuel from the 5MWe reactor will be shipped out of the country. It will either be reprocessed or just stored for a long time in the country that receives the spent fuel. If the destination is selected and agreed upon, the spent fuel may be shipped out of the country in ten years. To finish this in ten years, canning the spent fuel for shortterm storage before it is shipped should be done without any delay; shipping should also be prepared for well in advance with regard to packaging for overseas transport. To avoid difficulty in sustaining support, they have to agree that the HLW will not be shipped back to the DPRK after reprocessing.

Dismantling the 5MWe reactor to a level of irreversibility may be done in ten years, but it will generate various volumes and types of radioactive waste. The reactor and its cooling system may be the key components for irreversible dismantling. After dismantlement, the reactor must be periodically maintained and monitored to prevent radioactive leakage.

Analyzing the liquid HLW for traces of past activities can be done in a relatively short time. Dismantling the key components of the Radiochemical Laboratory-such as dissolver, mixer-settler, and hot-cells - to render it obsolete may be accomplished in less 
than ten years; however, managing the resulting waste problems cannot be finished in that short time.

Liquid HLW and ILW left at the site could be a serious problem. Liquid wastes may not only leak to the environment, but they could be attractive to those who would desire source material for a “dirty bomb.” The Radiochemical Laboratory must be well decontaminated to prevent radioactivity from leaking. It also requires periodic maintenance and monitoring.

Decommissioning activities that can be undertaken within ten years are limited. In considering CVID, the goal of verification via analysis of the liquid HLW, spent fuel, and swipe samples may be achieved. Although the goal of irreversibility of the facilities can be reached, much of the waste problem would remain unsolved. Thus the goal of completeness is not achievable through a fast-track approach. The waste problems that arise from the two facilities require additional investment of time and resources.

\subsection{Decommissioning Supported by International Cooperation}

The largest uncertainty in decommissioning is how to determine, fairly early, the responsible country (or countries) for long-term storage or reprocessing of spent fuel. That country should also be responsible for the vitrified HLW. Also, the verification of the decommissioning is a multilateral issue. Hence, decommissioning should be supported by international cooperation. Experts from the Six Party Talks countries and international organizations should be convened to provide technical support for the estimation activities.

The tasks for international cooperation should include:

1. Finding nonproliferation-supportive solutions.

2. Recognizing present technical status for waste treatment with regard to 5MWe and the Radiochemical Laboratory.

3. Estimating the amount of work.

4. Reporting economically feasible paths for decommissioning.

Regional sharing of responsibility for the decommissioning and the management of radioactive waste is the only practical approach, considering the need for and importance of cost-sharing, technical experience, regional security and nonproliferation concerns. 


\section{Conclusions and Recommendations}

The DPRK's plutonium relevant facilities were reviewed from the viewpoint of waste management that should be a key factor of decommissioning. The amount of spent fuel from the 5MWe reactor and the amount of liquid HLW and intermediate-level waste were estimated. It was found that decommissioning these two facilities would generate the solid and liquid wastes with a wide range of radioactivity.

The international status of decommissioning the nuclear facilities similar to the two DPRK facilities was reviewed. Most of the graphite reactors shut down in 1980s and 1990s in the UK, France, Italy, and Japan are found to still be in the planning phase, or at best in an initial phase of decommissioning. For reprocessing facilities, the Eurochemic reprocessing plant, which has been undergoing decommissioning for about 20 years, provided a good reference. In trying to estimate costs, it was found that we may not apply available reference data to the DPRK case, since we have to deal with many kinds of small-volume waste. What is clear, however, is that decommissioning graphite reactors is about an order of magnitude more costly than light water reactors, due to a larger volume of waste and the types of waste.

Provided that the destination is found, the spent fuel and the liquid HLW have to be shipped out of the country to reduce the threat and hazard. This will partly fulfill the goal of CVID. Fast-track decommissioning alone, implying the removal of key components and spent fuel in ten years by partly dismantling the facilities, would generate wastes and leave the waste problem unsolved.

No matter how we limit the activities of the decommissioning just to achieve the minimum goal of CVID, we cannot prevent the spent fuel and large volume of various types of waste from arising. To handle the wastes, the following facilities are needed:

- Immediate needs: canning station, dry storage pit, packaging station for overseas transport, decontamination facilities, and LLW storage

- Mid-term needs: decontamination and packaging stations for metal, concrete and graphite, LLW disposal site

- Long-term needs: interim storage facilities for HLW and ILW, disposal repository for HLW and ILW

CVID should be pursued together with a radioactive waste management plan, which includes technology, sharing of responsibility, and resources. Task-by-task approaches should be tried for successful results. The tasks for CVID are as follows: 
Task 1. Spent fuel and HLW

- plan to remove the spent fuel and liquid HLW and overcome technical hurdles as well as find the responsibility party to receive;

- receiver of the spent fuel and the liquid HLW will store and dispose of vitrified HLW; and

- need to investigate the issues including technical, political, legislative matters and public acceptance.

Task 2. Supporting early SAFSTOR

- need to investigate in advance radioactivity inventory estimation, removal tool development, canning and packaging of spent fuel and HLW, classification and segregation of waste, cost, etc.

Task 3. ILWs

- need to investigate the feasible ways to provide for interim storage and a disposal repository.

Despite the formidable scope of the radioactive waste management problem resulting from DPRK nuclear dismantlement, it is clear that there are also encouraging opportunities. Effective radioactive waste management is intrinsically a mutuallydesirable goal. Concerted efforts by other countries, not only the other regional players, but also those with technical resources and capabilities, and those with extensive experience in dealing with the similar dismantlement issues, can be brought to bear in a coordinated, cooperative engagement. 


\section{Appendix I: \\ Status of Graphite Reactor Decommissioning}

GCR decommissioning has begun in several countries and is instructive in considering options for the DPRK. The key information is summarized here:

\section{UK}

The UK government policy has two essentials for decommissioning: progressive and systematic reduction in hazards, and incorporating the flexibility to consider all relevant factors in determining the strategic timing of the process. The UK finds the technical and safety benefits upon which the strategic timing is based and the financial advantage of the strategic timing.

After many years of consideration and modifications, the UK's final strategy for decommissioning GCRs is based upon early SAFSTOR and a long deferral time (up to 100 years). In this strategy fuel is withdrawn after reactor shutdown and most plant systems are removed. The ILW (graphite and other waste with long-lived radionuclides) is packaged and stored on-site until a proper disposal repository is available. The site remains under constant surveillance and is subject to a rigorous program of inspection and maintenance. After a period of at least 85 years from end-of-generation, the reactor is finally dismantled and the site is remediated for reuse.

The UK shut down 14 of its 26 Magnox reactors during the late 1980s and early 1990s. The Calder Hall reactors were shut down in 2003.

Decommissioning the Windscale Advanced Gas Cooled Reactor (WAGR), shut down since 1981, began in 1998 after many reviews and modifications on decisions. WAGR, which operated from 1963 to 1981 with a rated power of 32MWe, had served as a test bed for development of fuel and other components for commercial reactors. It has since become a demonstration project for power reactor decommissioning. Although not a Magnox reactor (it used uranium dioxide fuel in stainless steel cladding), WAGR has a huge graphite moderator, $15 \mathrm{ft}$ in diameter and $14 \mathrm{ft}$ high, housed in a cylindrical reactor vessel with hemispherical ends. A preliminary study for decommissioning started in 1975. In 1981, when the reactor was shut down, it was decided that WAGR decommissioning would restore the area occupied by the facility to a condition of unrestricted re-usability. In 1993 a project review to relieve the government financial burden redefined the project objectives to complete the core and reactor vessel decommissioning, but defer the demolition of the bioshield and containment building. As part of the WAGR decommissioning, many remote handling machines were developed, a waste packaging plant for LLW and ILW was built, and a waste storage building for ILW was also built pending acquisition of a disposal site for ILW. The removal of the core and pressure vessel was divided into a series of 10 campaigns, which began in 1998 and is expected to be finished by 2006. WAGR will then become the first GCR to be decommissioned to the level of SAFSTOR. 


\section{France}

France's strategy involves restoring GCR sites after decommissioning, allowing up to 50 years from the start of the decommissioning phase to the final restoration of a site. France needs to build a disposal repository for the specific waste from GCRs.

France once owned nine GCR nuclear power plants. All have been shut down, mostly during the 1980s and early 1990s. Apart from research reactors, they were G1, G2, G3 at Marcoule (Gard), Chinon A1, A2, and A3 (Indre-et-Loire), Saint-Laurent-des-Eaux A1 and A2 (Loir-et-Cher), and Bugey 1 (Ain). The first GCR reactor, G1, was put into service in 1956, the last, Bugey 1, in 1972. At the end of the 1960s, Electricite de France (EDF) decided to abandon the GCR line and instead use pressurized water reactors.

Chinon A1 has been partially dismantled to "level 1" and the core confined within a steel-concrete envelope. The building that houses it, a metallic sphere, has been transformed into a museum that is open to the public. It was estimated that the total quantity of contaminated or radioactive materials to be taken apart amounts to 3680 t plus 1600 drums of technological waste. The 3680 t includes $1100 \mathrm{t}$ of contaminated graphite. Complete dismantling is planned for 2027.

Chinon A2 was partially dismantled to level 2 in 1992. The reactor block, which contains $1800 \mathrm{t}$ of graphite, is confined. Four buildings on the site house steam generators and the primary coolant circuit, which has been cut up. The estimated mass of all the radioactive or contaminated material, including graphite, is 7945 t, plus 2000 drums of technological waste. Total dismantling is planned for 2039.

Partial dismantling of Chinon A3 to level 2 began in 1997. The mass of contaminated and activated materials, including $2500 \mathrm{t}$ of graphite, is estimated to be $7560 \mathrm{t}$ plus 3700 drums of technological waste. The activity of the graphite is estimated at $7800 \mathrm{TBq}$. Total dismantling is planned for 2044.

G2 and G3 have been dismantled to level 2. They cannot be dismantled to level 3 without a means of dealing with the graphite. The wastes stored at G2-G3 include $24.1 \mathrm{t}$ of technological solid waste packed in drums, $544 \mathrm{t}$ of slag packed in drums, $4 \mathrm{t}$ of fines from the melting process also in drums, $4060 \mathrm{t}$ of metal blocks and ingots resulting from melting, 902 t of containers made from melted metal, and seven casks with control rods (4.1 TBq). The cores of G2-G3 contain $2400 \mathrm{t}$ of graphite $(0.83 \mathrm{PBq})$ and $2900 \mathrm{t}$ of activated steel.

\section{Italy}

The Latina nuclear power plant was a Magnox reactor with a net capacity of 153 MWe. It was shut down in 1987 after operating for 24 years. After reactor shutdown, the fuel was removed and sent to Sellafield (UK) for reprocessing. The decommissioning plan for Latina consists of four major stages: site preparation, core retrieval, construction of a waste management facility, and site clearance. The main decommissioning work will begin in 2005, with current plans to finish by 2020. 


\section{Japan}

In 1966, Japan started Tokai-1, the country's first commercial and only Magnox-type power reactor, which operated for 32 years at a rated power of 159MWe. Japan now plans to dismantle Tokai-1 under the option DECON (restoring the site). Japan Atomic Power Company (JAPCo), the owner of the plant, estimated the decommissioning project would last about 17 years.

In the first phase, from 2001 to 2005, preparatory work will be done, including draining the spent fuel pools and removing the turbines. In the second phase, from 2006 to 2010, auxiliary facilities, such as heat exchangers, will be removed. In the final phase, from 2011 to 2017, the core and reactor building will be removed. Prior to beginning the final phase, JAPCo plans to develop a disposal site for specific waste from Tokai-1. The project is expected to cost 93 billion yen (about USD 750 million). 
Dismantlement and Radioactive Waste Management of DPRK Nuclear Facilities

This page left intentionally blank. 


\section{Appendix II: International Precedents for Reprocessing Facility Decommissioning}

In considering the DPRK Radiochemical Laboratory, it is helpful to review how decommissioning the Eurochemic plant was planned and has progressed. French reprocessing facility decommissioning is also reviewed.

\section{Eurochemic Facility Decommissioning}

The decommissioning activities at the Eurochemic reprocessing plant highlight the fact that an industrial scale decommissioning can be carried out by adopting commercially available technology with special emphasis on waste minimization and extensive decontamination for unconditional release.

From 1966 to 1974, the Eurochemic reprocessing facility in Belgium was operated as a demonstration plant for a consortium of 13 OECD countries. 180 metric tons of natural and low-enriched uranium and 30 metric tons of high-enriched uranium fuel were reprocessed. In 1986, Belgium decided not to resume reprocessing.

In 1987, a report on the technical and financial aspects of decommissioning the Eurochemic reprocessing facility was submitted. The total cost of the decommissioning operation was estimated at about 300 million USD, of which about 156 million USD represented the first stage of the work to be done. The first stage included the reprocessing plant, its analytical laboratory, the storage facilities for the final products of reprocessing and storage tanks for high- and intermediate level liquid waste. In addition, the cost of managing all the waste was estimated at 10 billion BF, spread over a period of about fifty years. This cost does not include construction or operation of a geological repository.

For the first stage of decommissioning, a detailed estimate was made of the quantities of radioactive waste to be generated. Waste was categorized as either primary or secondary. The primary waste is of two kinds:

- one to be disposed of in deep geological formations (content of alpha emitters above $10 \mathrm{Ci} /$ ton of conditioned waste), including 230 metric tons of metal, 30 metric tons of concrete, and 12 cubic meters of special wastes;

- another to be buried at shallow depth (content of alpha emitters below $10 \mathrm{Ci} /$ ton of conditioned waste), including 3,235 metric tons of concrete and 180 cubic meters of special waste.

The secondary waste represents low activity liquid wastes, combustible wastes, and compactable wastes.

The main process building is large: $80 \mathrm{~m}$ long, $27 \mathrm{~m}$ wide, and $30 \mathrm{~m}$ high. About 106 cell structures had to be dismantled, estimated at 1500 metric tons of metal structure and $12,500 \mathrm{~m}^{3}$ of concrete $\left(55,000 \mathrm{~m}^{2}\right.$ concrete surface area) to be removed or decontaminated.

A pilot decommissioning project on two small storage buildings for end products from reprocessing was finished, and concluded that emphasis should be put on automating the 
decontamination of metal components and concrete. The two buildings were demolished and the remaining concrete was disposed of as industrial waste. The site attained "green field" conditions.

Industrial scale decommissioning of the main building was started in 1990, after completion of the pilot project, and is expected to last until mid 2006. As of the end of 2001, 90 of the 106 individual cells have been subject to decommissioning work. Of the 90 cells, 33 cells were completely dismantled and decontaminated; removal of components was being undertaken with the rest of the cells. 550 metric tons of metal and about one million $\mathrm{m}^{3}$ of concrete were generated as waste. Much effort has gone into decontamination and the unconditional release of solid material: $66 \%$ of metal, $94 \%$ of heavy concrete and about $40 \%$ of other materials were decontaminated to be released unconditionally.

Apart from the operational liquid waste coming from decommissioning work, high level liquid radioactive waste needed special treatment, i.e., vitrification. A type of high-level liquid waste from reprocessing of natural and slightly enriched uranium fuel was transferred to PAMELA, a vitrification facility in Germany. The transferred waste amounted to $48.9 \mathrm{~m}^{3}$ from the 181 metric tons of reprocessed uranium fuel, and was then about 7.9 million Ci. A series of campaigns lasting between October 1985 and May 1986 produced a total of 540 containers, of which 440 contained glass blocks and 100 contained glass beads called VITROMET. Each glass block weighs about $154 \mathrm{~kg}$ and shares about 0.11 cubic meters of waste, corresponding to $18,000 \mathrm{Ci}$. The total volume of glass produced was 30 cubic meters and weighed 77.7 metric tons. Through vitrification, the volume of waste was reduced: one liter of high-level liquid waste produced 0.68 liter of glass, weighing $1.77 \mathrm{~kg}$. The cost of vitrification was about 9.4 million USD (191 USD per liter) in 1986.

\section{France}

AT1 was built for the reprocessing of fuel from Rapsodie and fast reactor fuel, and had been operated from 1969 to 1979. Nominal capacity was 1 kg-U/day. Dismantling began in 1983 and completed in 2001 to restore the site.

UP1 was built to reprocess fuels from the gas cooled graphite reactors, G1, G2 and G3. From time to time during the period of its operation from 1958 to 1997, UP1 also received fuel from the reactors of EDF, Phoenix and some other research reactors. Since its commissioning in 1958, UP1 has handled 18,600 metric tons of fuel. Process lines have been added and modified to meet the various requirements for reprocessing. Since 1998, UP1 has been in the final shutdown phase. This will be followed by the beginning of decommissioning operations, which involves retrieval and repackaging of historical waste. The decommissioning of UP1 is scheduled to last about thirty years. 


\section{About the Authors}

Jooho Whang is Professor of Nuclear Engineering with special expertise in Radioactive Waste Management and Radiation Engineering. He is currently General Secretary of the Korean Nuclear Society; he is also a member of the American Nuclear Society, the Korean Association of Radiation Protection, and the Committee for Enhancement of Nuclear Power Plant Technology in the Korean Ministry of Commerce, Industry and Energy. From 1999-2001, he served as the Nuclear Program Coordinator for the Korean Institute of Science and Technology, Evaluation and Planning, where he was entrusted by the Korean Ministry of Science and Technology with evaluation, planning and management for the Korean national nuclear R\&D program. He has worked previously for the Korean Atomic Energy Research Institute (KAERI). His PhD (Nuclear Engineering) is from Georgia Tech..

George Baldwin is a member of the technical staff at Sandia National Laboratories and the Cooperative Monitoring Center. At the CMC, his major interest is in technical verification and confidence building measures for nuclear nonproliferation, including international safeguards, the Additional Protocol, fissile material cutoff, disposition of excess materials, and related issues. His principal expertise is in radiation detection, nuclear instrumentation and measurements applied to reactors, particle accelerators, and inertial fusion machines. George worked previously for the Safeguards Department at the International Atomic Energy Agency in Vienna, Austria. He is a member of the American Physical Society and the Institute for Nuclear Materials Management. He holds a B.A. degree in physics from Kalamazoo College and Ph.D. in nuclear engineering from the University of Michigan.

\section{Distribution}

350 MS $1371 \quad$ CMC Library, 6929

1 MS 9018 Central Technical Files, 8945-1

2 MS 0899 Technical Library, 9616 
Dismantlement and Radioactive Waste Management of DPRK Nuclear Facilities

This page left intentionally blank. 